\title{
Transition Period of the Dairy Cow Revisited: I. Homeorhesis and Its Changes by Selection and Management
}

\author{
Holger Martens ${ }^{1}$ \\ ${ }^{1}$ Institute of Veterinary Physiology, Freie Universität Berlin, Berlin, Germany \\ Correspondence: Holger Martens, Institute of Veterinary Physiology, Freie Universität Berlin, Oertzenweg 19b, \\ 14163 Berlin, Germany. Tel: 049-30-831-1805. E-mail: holger.martens@fu-berlin.de
}

Received: November 28, 2019

Accepted: January 30, 2020

Online Published: February 15, 2020

doi:10.5539/jas.v12n3p1

URL: https://doi.org/10.5539/jas.v12n3p1

The research is financed by the Margarete-Markus-Charity and the Bundesministerium für Bildung, Wissenschaft und Forschung.

\begin{abstract}
The transition period of the dairy cow involves the end of pregnancy, parturition, and the onset of lactation. Multifaceted and rapid changes occur during this time, and in particular, the increase of milk secretion requires the large-scale reorientation of metabolism. The underlying mechanisms of this metabolic regulation are collectively named homeorhesis, a process that governs milk production during this phase and that exhibits (A) a chronic nature, (B) the simultaneous inclusion of multiple tissues, and (C) altered responses to homeostatic signals, but (D) no direct feedback mechanisms for possible control or limitation. Priority of milk production is one important consequence of this homeorhetic regulation with possible constraints on other physiological functions. These general properties of the homeorhetic regulation of milk secretion are specifically characterized by a) milk production according milking (suckling) frequency, b) a natural but inadequate dry matter intake, c) the mobilization of fat acids + glycerol from adipose tissue and of amino acids from protein, d) the partitioning of metabolites, IgG, and dietary nutrients to the mammary gland, e) the stimulation of milk production by high protein intake, and f) a negligible negative energy balance (NEB) at low milk production. Such a combination assures the optimal milk yield for the nutrition of the calf and for its successful survival but without a metabolic challenge or health risk for the cow. However, selection for higher milk production (uncoupled from calf nutrition) and management have changed the above-listed properties, and the regulation of homeorhetic milk production of the modern high-producing dairy cow is nowadays mostly characterized by a) increasing and maximal milk production at increased milking frequency and, under certain circumstances, the uncoupling of the GH-IGF-1 axis, b) enduring insufficient dry matter intake in relation to requirement, c) the mobilization of energy (lipolysis) and release of non-esterified fatty acids (NEFA) above the acute requirement, d) the mobilization of amino acids, e) the partitioning of metabolites, IgG, and dietary nutrient to the mammary gland, f) the potential enhanced partitioning of energy to the mammary gland at high CP intake, g) a sudden and long-lasting NEB, and h) possibly lower weight gain or even net loss of energy during the entire lactation period. These altered and often unfavorable characteristics of high milk production are, furthermore, still regulated by homeorhesis and are thus also given top priority, lack feedback control, and possibly ensue at the expense of other functions without regard for health risks. Hence, the promotion of milk yield by breeding or management might cause metabolic overload, imbalances, or even antagonisms and makes possible health hazards evident. The high incidence of various diseases, the untimely culling rates, and the increasing number of dead cows during early lactation support the assumption of general health threats at high milk production. For this reason, more attention should be paid to the physiological mechanisms of homeorhetic-regulated milk production, its indisputable alterations by breeding and management, and the resulting health risks.
\end{abstract}

Keywords: homeorhesis, nutrition, negative energy balance, production diseases

\section{Introduction}

"Transition period is defined as 3 weeks prepartum and 3 weeks postpartum" (Grummer, 1995). During this time, pregnancy is completed, parturition occurs, and milk production begins. "There is no other time in a cow's life that is more tumultuous" (Grummer et al., 2004). The most tumultuous part of this whole process is probably the 
increase in the nutrient requirement of the cow postpartum (p.p.) as a result of rapid increasing milk production. "At parturition, demand for all nutrients doubles within a few days and within a few weeks can be 3-5 times as high as in mid gestation" (McNamara, 2004).

These rapid and multiple changes during early lactation require a complex regulation of metabolism for the successful adaptation of the cow to its new challenges and have been excellently outlined in detail by Bauman and Currie (1980), Vernon and Pond (1997), Chilliard et al. (1998), Bauman (2000), Renaville et al. (2002), Boisclair et al. (2006), Baumgard et al. (2017). Two mechanisms dominate regulation. The first, viz., homeostasis, is an acute and short minute-by-minute regulating system for keeping constant internal conditions such as body temperature, blood glucose concentration (Bauman \& Currie, 1980), or pH and acid-base metabolism. The second has been coined by Bauman and Currie (1980) as "homeorhesis" and involves the "orchestrated or coordinated changes for the priorities of a physiological state, i.e., coordination of metabolism in various tissues to support a physiological state"; the homeorhetic "physiological state" of the cow p.p. being milk production.

Homeorhesis is a wide-spread control system in biology and includes the regulation of growth, pregnancy, or hibernation (Bauman, 2000); it has (A) a chronic nature, influences (B) simultaneously multiple tissues, and mediates (C) altered responses to homeostatic signals (Bauman, 2000). Surprisingly, homeorhesis of milk production does not exhibit (D) a direct feedback mechanism, although this essential step of regulation and control is well known in other homeorhetic systems such as growth, pregnancy or hibernation. Instead, the appetite of the calf is proposed as a biological and indirect feedback and "control mechanism" for (limiting) milk yield. These general characteristics of homeorhesis (A-D) provide the framing conditions for understanding the regulation of lactation and metabolism and include specific mechanisms that together determine optimal milk production for the nutrition and survival of the calf: a) milk production according milking (suckling) frequency, b) inadequate dry matter intake, c) the mobilization of fat acids + glycerol from adipose tissue and of amino acids from protein, d) the partitioning of metabolites, IgG, and dietary nutrients to the mammary gland, e) the stimulation of milk production by high protein intake, and f) a negligible negative energy balance (NEB) at low milk production. However, the general and specific mechanisms of lactational homeorhesis have been substantially changed by selection for higher milk yield (MY) and by management.

The intention of these reviews (part 1 and 2) is to summarize the physiological background of the homeorhetic regulation of milk production and metabolism, to indicate the changes to this background by genetic and by management, and to point out some of the challenges of these changes as possible health risks. This approach will show possible interactions and connections between the issues of homeorhesis, negative energy balance, metabolic challenge, and health risks. These reviews are not systematic (O'Connor \& Sargeant, 2014) and primarily do not contain details (for these, see the links to corresponding reviews); hence, they are not presented with any claim to completeness but aim at disclosing an unbroken ("red") thread that links these topics and at encouraging a discussion of these topics as a complex rather than as a single or separate event (Sordillo \& Mavangira, 2014; see part 2).

\section{Homeorhetic Mechanisms and Changes}

\subsection{Milk yield}

The "physiological (homeorhetic) state" p.p. includes milk production with a high priority and the possible drawbacks generated by neglecting other physiological functions. Originally, this process was dedicated to the nutrition of (only) one calf with some 500-1000 1 per lactation. Such production can hardly be considered as a metabolic challenge because the energy requirement at the end of pregnancy accounts to $38 \mathrm{MJ}_{\mathrm{NEL}} / \mathrm{d}$ for the maintenance of the cow and $18 \mathrm{MJ}_{\mathrm{NEL}} / \mathrm{d}$ for the calf, uterus, and mammary gland (Gesellschaft für Ernährungsphysiologie-GfE, 2001), with $18 \mathrm{MJ}_{\mathrm{NEL}} / \mathrm{d}$ being sufficient for some 51 milk after parturition. Indeed, body weight increases after the parturition of Hereford cows producing milk only for their suckling calves (Hart et al., 1975).

Milk production during early lactation can be stimulated by the frequency of milking (Wall and McFadden, 2012), and naturally, the appetite and the suckling frequency of a calf represent a regular trigger for the feedforward increase of milk production. Conversely, the feeling of satiety in the calf serves as an indirect feedback mechanism for limitation. Hence, the regulation of the amount of milk is the combination of feedforward (frequency) and feedback (appetite) mechanisms and guarantees an optimal amount for the nutrition of the calf and the metabolic capacity of a cow with minor health risks. 


\subsection{Changes of Milk Yield}

Milk production per lactation has increased in Germany by a factor 3 from $2600 \mathrm{~kg}$ in the 1950 s to almost 8000 $\mathrm{kg}$ in 2017 (mean of all breeds) (BRS, 2018). Single cows or herds frequently produce much more milk, and MY of $11000-12000 \mathrm{~kg}$ or even more are often produced in countries with intensive milk production aims. The genetic trend for milk production has increased in the USA from $37 \mathrm{~kg}$ in the $1960 \mathrm{~s}$ to $116 \mathrm{~kg}$ per lactation in the 1990s (Hansen, 2000), and production has further increased to $10328 \mathrm{~kg}$ in 2016 (Baumgard et al., 2017). Levels of $11970 \mathrm{~kg}$ have been reported in Israel (Israeli Dairy Board, 2017).

MY shows high heritability in early lactation (Hüttmann et al., 2009) and a high priority in the breeding index of Holstein Friesian (HF) cows in Germany (Deutsch Holstein, 2017). Further increases of MY will probably occur in the future.

The increase of milk production by frequent milking during early lactation has been studied by Bar-Peled et al. (1998). The authors have observed an increase of milk production from $38 \mathrm{~kg} / \mathrm{d}$ to $52 \mathrm{~kg} / \mathrm{d}$ at a higher frequency of milking or at milking ( 3 times) combined with suckling (3 times); this suggests the stimulation of the feedforward signal by frequency and the offset of biological feedback, i.e., limitation by the appetite of the calf. The optimal MY for calf nutrition has been replaced by maximal MY without a corresponding dry matter intake.

\subsection{Dry Matter Intake (DMI)}

Feed intake declines before parturition and slowly increases afterwards compared with the rapid enhancing milk production, thereby causing a gap between output and input or a negative energy balance (NEB). Many studies of this topic have been undertaken and reported (Chilliard et al., 1998; Ingvartsen \& Andersen, 2000; Grummer et al., 2004; Dann et al., 2006; Allen \& Piatoni, 2013; Van Saun \& Sniffen, 2014). The genetic correlation between DMI before parturition and $30 \mathrm{~d}$ p.p. is high (Shonka et al., 2015), but the periparturient decline remains poorly understood (Allen, 2000; Kuhla et al., 2016).

However, some biological explanations have been suggested. The decline of DMI before parturition might be explained by the growing calf in the uterus and the resulting space limitation in the abdomen. This physical restriction is eliminated at parturition and should permit the rapid increase of DMI, but this does not occur. Gravert (1985) mentions "that the curve of feed intake (p.p. the author) still corresponds to the non-domesticated cow in according with the requirement of the suckling calf while the lactation curve has been altered by artificial selection for higher milk yields". Vernon and Pond (1997) have discussed this problem from a comparative and biological point of view (not directly for the cow) and stated: "The inappetance around parturition is probably a throwback to the wild state when mothers would need to remain at the nest for a period of time and at this time would be unable to feed". The wild cow (Bos taurus) would go into the underwood during parturition with a reduced appetite and would not forage because it was primarily taking care of the new born calf. Knight (2001) has made some suggestions in the same (biological) direction and pointed to some advantages of a reduced DMI "Energetically, mobilization confers approximately $80 \%$ efficiency, whilst digestion is only $60 \%$ efficient", and "there is less need for physical activity (foraging)." "Perhaps, the real conundrum is why so much effort is exerted by agricultural nutritionists and dairy farmers in trying to persuade the early-lactation cow to eat more. She knows better!" Indeed, this is probably the case. Milk production (homeorhesis) has priority over DMI, and milk secretion for the nutrition of the calf is (at least) partially independent of it. This could be important under conditions in the wild. A harsh climate in spring during calving and the poor nutritional circumstances consequently do not challenge milk production and the nutrition of the calf. The reduced time for seeking or eating grass increases the period for the cow to attend the calf and to improve its survival rate.

The biological suggestions of Gravert (1985), Vernon and Pond (1997), and Knight (2001) are strongly supported by genetic studies. A negative genetic correlation exists p.p. between milk yield and dry matter intake (Karacaören et al., 2006; Liinamo et al., 2012; Manzanilla-Pech et al., 2014). It confirms the early observation of Veerkamp and Thompson (1999) that feed intake is negatively correlated with milk yield and with blood oxytocin concentration (Bar-Peled et al., 1998). Recently, a positive genetic correlation between MY and DMI has been described by Krattenmacher et al. (2019). The correlation is low at the onset of lactation (= 0.09 at $d 11$ in milk) and consequently, a strong negative genetic correlation has been found between MY and energy balance. The insufficient DMI around parturition is primarily of biological (genetic) origin: "She (the cow, the author) knows better" (Knight, 2001). This conclusion is supported by the studies of Grummer et al. (2004). Parity, body condition score, and various diet components only explain $18 \%$ of the variation of DMI at 3 weeks before parturition (Grummer et al., 2004). This does not exclude other management factors but clearly indicates the physiological (genetic) background that primarily determines the dip in DMI around parturition. A consequence is NEB and loss of body weight. "These patterns could not be accounted for by environmental factors such as 
constrained intake or condition score at calving" (Friggens et al., 2007) and strengthen the influence of the genetic and biological background.

\subsection{Changes of Dry Matter Intake}

Selection for high MY has not involved selection for higher DMI according to requirement p.p., because recording DMI for individual cows is impractical (Banos \& Coffey, 2010) and hence, the equivalent parameters are not known. As a consequence, milk production in the USA has been increased by some $57 \%$ over 23 years (1980-2003), but DMI unproportionally only by some $20 \%$ (Eastridge, 2006) and "this results in a more or less extended negative energy balance and increased mobilization of body reserves". DMI intake during lactation was recently determined in an international co-operation between Austria, Switzerland, and Germany. The regression coefficient between MY and DMI was only by $0.1 \mathrm{~kg}$ DM per kg milk during early lactation (Gruber et al., 2006) and agrees with the low correlation observed by Krattenmacher et al. (2019). The low coefficient of DMI per kg milk clearly indicates that this additional DMI does not cover the MY-dependent increase in requirement and means that the NEB increases with higher milk production after parturition, despite the positive correlation with (low) DMI per kg milk. It is worth mentioning that, in a recent review about DMI, the model of Gruber et al. (2006) predicted the DMI (total mixed ration) most accurately (Jensen et al., 2015). Interestingly, the low coefficient between milk production and DMI (0.1) was noted decades ago by Bines (1976), and the same magnitude of 0.12-0.14 was observed by Veerkamp and Koenen (1999). Furthermore, these authors summarized data from three studies with high- and low-producing cows. Milk production increased in high-producing cows without an equivalent increase of DMI. Hence, during early lactation, MY is relatively uncoupled from DMI, as was mentioned as early as 1985 (Brandt et al., 1985). The current breeding index with its high priority for MY is thus outpacing adequate nutrition and exacerbating NEB. As a consequence, a negative genetic correlation is observed between MY and energy balance (Spurlock et al., 2012), particularly during early lactation (Krattenmacher et al., 2019).

In order to compensate for low DMI and to alleviate the NEB and mobilization, diet density has been increased mainly by the addition of starch, and $\approx 7.0 \mathrm{MJ}_{\mathrm{NEL}} / \mathrm{kg}$ DM or even more is now typical for high-producing dairy cattle. However, "attempts to abolish lipid mobilization in early lactation by feeding energy rich diets are in general not successful" (Friggens \& Newbold, 2007), as have been observed by Andersen et al. (2003): "Milking multiparous cows three times a day compared with two times daily for the first 8 weeks of lactation, whether fed a low or a high concentrate level diet, increased milk yield by $8 \%$ without a corresponding increase in feed intake. As expected, cows milked three times a day had the biggest weight loss, which was most pronounced in cows fed the low concentrate level diet". However, a glucogenic vs. a lipogenic diet with almost an identical $\mathrm{MJ}_{\mathrm{NEL}} / \mathrm{kg} \mathrm{DM}$ of the diet improves the energy balance during early lactation and reduces the fat liver content (van Knegsel et al., 2007a).

Starch stimulates fermentation and the production of propionate, which unfortunately has hypophagic effects caused by the hepatic oxidative theory leading to decreased DMI (Allen \& Bradford, 2012; Gualdrón-Duarte \& Allen, 2017), i.e., the exact opposite to the required higher DMI. A further metabolic change probably contributes to low DMI. A decrease of DMI occurs before parturition, and concentrations of NEFA increase a.p. with a peak p.p. (Sheehy et al., 2017). Flow of NEFA to the liver during high lipolysis also has hypophagic effects (Scharrer, 1999; Allen \& Piantoni, 2013), as does beta-hydroxybutyrate (BHB) (Scharrer, 1999), thereby confirming the negative correlation between BHB and DMI (Lean et al., 1992). In agreement with these anorexic findings for $\mathrm{BHB}$, the $\mathrm{BHB}$ concentration increases in the cerebrospinal fluid of cows p.p., although the underlying anorexic mechanism is not clear (Laeger et al., 2013).

Energy density has an additional side impact. Increasing concentrate competitively decreases roughage intake (Faverdin et al., 1991). The compensation of the genetically dependent dip of DMI by energy density seems to lead to hypophagic effects and to inadequate roughage intake with the risk of displaced abomasum (Cameron et al., 1998).

The insufficient DMI p.p. also includes the under-nutrition with protein (Bell et al., 2000). In practice, the protein deficit is compensated by the increased crude protein (CP) content of the diet p.p. It enhances milk production and, in some cases, DMI (Oldham, 1984) with a possible increase of NEB (Ørskov et al., 1977; Oldham, 1984; Larsen et al., 2014). Potential side effects are discussed below.

\subsection{Partitioning and Mobilization}

A key issue of the homeorhetic regulation of early lactation is the partitioning of nutrients. The high demand of nutrients for milk production at insufficient DMI requires careful allocation, which is (amongst others) predominantly regulated by changes of GH, insulin, and IGF-1 concentrations and insulin resistance (IR) in 
selected tissues such as striated muscle and fat tissue (for details, see Bauman \& Currie, 1980; Bell et al., 1987, Vernon, 1989; Vernon \& Pond, 1997; Chilliard et al., 1998; Vernon, 1998; Bauman, 1999; Etherton \& Bauman, 1998; Bauman, 2000; McNamara, 2015; Collier \& Bauman, 2017; Baumgard et al., 2017). As a consequence of these hormonal adjustments, flux rates of important nutrients are changed with the priority being milk production. Briefly, the following alterations are observed.

Glucose: Gluconeogenesis is stimulated by GH (Bauman et al., 1988) and increases four-fold in superior lactating cows p.p. (Bell \& Bauman, 1997). The uptake of glucose by non-mammary tissue is reduced, and the oxidation of glucose is diminished, both of which direct the spared glucose to milk production (Bauman, 2000). These modifications in glucose metabolism are caused by altered hormonal concentrations and responses to homeostatic signals. Growth hormone $(\mathrm{GH})$ is increased p.p. causing insulin resistance in muscle and fat tissue (Vernon, 1989; Bell et al., 2000). IR is pronounced in adipose tissue in cows with high weight loss, but IR does not occur in the liver (Zachut et al., 2013). A growing body of evidence suggests that inflammation is involved in p.p. IR, and inflammation-dependent IR is thought to be an adaptive response of homeorhetic adaptation in early lactation (Farney et al., 2013; Montgomery et al., 2019).

IR is accompanied by low insulin concentrations (Vernon, 1989; Bell et al., 2000). Hart et al. (1978) observed an inverse relationship between insulin and MY; this has been confirmed by a strongly negative correlation between insulin and MY (Wathes et al., 2007). Recently, Zinicola and Bicalho (2019) have found that, in dairy cows during early p.p., low insulin concentrations are related to higher milk production. Furthermore, low insulin is associated with a high loss of BCS and higher NEFA concentrations.

NEFA: A further step in partitioning is the allocation of mobilized fat. The energetic deficit is compensated by the mobilization of NEFA ( + glycerol) from adipose tissue. Plasma NEFA concentrations are used for oxidation and particularly for milk synthesis and are highly correlated with their irreversible loss rate (Bauman et al., 1988).

Lipolysis is stimulated by GH and by an increased response and sensitivity to catecholamines via the increased number of $\beta$-receptors (Vernon \& Pond, 1997; McNamara, 2015; Contreras et al., 2017). An aspect that is very often overlooked is that insulin is integrated into the liporegulatory feedback mechanisms by NEFA and ketone bodies (Herdt, 2000). Fatty acids containing 3-8 carbon molecules, namely propionate or butyrate, stimulated insulin secretion in ruminants (Horino et al., 1968), and lipolysis with an increase of NEFA in mice triggers the release of insulin (Heine et al., 2018). Insulin stimulates lipid synthesis and inhibits lipolysis (Herdt, 2000), thereby representing a negative feedback on lipolysis. However, this possible effect is reduced because the high demand of the mammary gland for glucose at reduced glucose concentrations decreases the insulin concentration, which is associated with IR p.p. (Vernon \& Pond, 1997) (for details of IR: see De Koster \& Opsomer, 2013). Further, the effect of insulin on lipid synthesis is inhibited in the presence of GH (Vernon, 1998). Hence, the mobilization of NEFA is a combined effect of the stimulation of lipolysis by GH and the inhibition of lipogenesis by low insulin concentration and IR and represents a transformation from an anabolic status a.p. to a catabolic one p.p. Mobilization occurs above the acute requirement with an increase of NEFA concentrations in the blood and ectopic fat deposition in the liver, muscle, and other organs (Reid \& Roberts, 1982).

"The observed mobilization in early lactation is largely genetically driven" (Friggens \& Newbold, 2007), and high genetic merit dairy cows exhibit an increased sensitivity of adipose tissue for lipolysis (McNamara \& Hillers, 1986). A genetic background for mobilization is suggested by the data of Bertics et al. (1992). An increase of NEFA a.p. and $+1 \mathrm{~d}$ relative to calving has also been observed to the same extent in both control and experimental cows, although the experimental cows were maintained a.p. at the same level at DMI by force-feeding the refusals via the rumen fistula or without the dip of DMI before parturition (Bertics et al., 1992).

Amino acids: Proteolysis occurs in cows p.p. for the limited time of 23 days (Bell et al., 2000) or sometimes 5 weeks and at an amount of 4.6 and 21 kg p.p. (Tamminga et al., 1997; Komaragiri \& Erdman, 1997). The amino acids are used for gluconeogenesis and milk protein synthesis (Bell et al., 2000). Some evidence suggests that the period of negative protein balance is extended. Metabolizable protein balance is still negative 6 weeks p.p. (Mann et al., 2016). Proteolysis via proteasome activity occurs before calving and is upregulated p.p. (Mann et al., 2016). Furthermore, an increase of macro-autophagy as a further mechanism of proteolysis has been observed p.p. The authors integrate these proteolytic pathways into the homeorhetic adaptation of NEB (Mann et al., 2016) and suggest that this explains the longer proteolytic period p.p. NEB and proteolysis might be connected. NEFA at parturition is positively correlated with the concentration of 3-methylhistidine, an amino acid produced by protein degradation (Akamatsu et al., 2007). Furthermore, BHB stimulates chaperone-mediated 
autophagy (proteolysis) in a cell culture system (Finn \& Dice, 2005). The increase of BHB is not restricted to the early phase p.p. Mahrt et al. (2015) have concluded that the risk of hyperketonemia last at least until week 6 p.p.

Perhaps low IGF-1 p.p. indirectly aids proteolysis because the stimulating effect of IGF-1 on protein synthesis and the inhibition of degradation are reduced (Etherton, 1982). In fact, IGF-1 is a potent supporter of muscle growth (Schiaffino et al., 2013) and correlates with striated muscle growth (Velloso, 2008).

Immunoglobulin $\operatorname{IgG}$ : An important but very often overlooked aspect of partitioning is the transfer of immunoglobulins to colostrum. Van Knegsel et al. (2007b) determined natural antibodies in blood and colostrum and hypothesized "that the partitioning of natural antibodies between plasma and milk parallels the partitioning of energy". Herr et al. (2011) have corroborated this transfer. The IgG decline in blood a.p. is positively correlated with the IgG concentration in colostrum and supports the tendency for an inverse relationship between natural antibodies in plasma and milk (van Knegsel et al., 2007b). The transfer of IgG is independent of high or low concentrate supplementation before parturition (Eger et al., 2017) and confirms the priority of homeorhetic milk production with an IgG transfer uncoupled from energy intake. The decrease of IgG before parturition and the slow recovery p.p. (Herr et al., 2011) might significantly contribute to the immunosuppression of dairy cows during transition (Aleri et al., 2016). A decrease of $\mathrm{IgG}$ around parturition has not been observed in horses (Warko \& Bostedt, 1993).

Infection and partitioning: Evidence indicates that "immunostimulation" (infection, the author) homeorhetically alters systemic metabolism in a coordinated effort to meet the energetic demands of leukocytes (Horst et al., 2018). Glucose is obligatory for the energy metabolism of immune cells, and a shift to its metabolism occurs with a requirement of approximately $1 \mathrm{~g}$ glucose $/ \mathrm{kg} \mathrm{BW}^{0.75}$ per hour after an LPS challenge (Horst et al., 2018) or of $>1 \mathrm{~kg}$ glucose within $720 \mathrm{~min}$ (Kvidera et al., 2017), an effect that will impair other functions.

\subsection{Changes of Partitioning and Mobilization}

An increase of GH and a decrease of insulin and IGF-1 concentrations are the predominant hormonal alterations occurring at this phase, and insulin resistance (IR) represents a change of a set point p.p. as a general characteristic of homeorhesis (Vernon, 1998; Etherton \& Bauman, 1998; Bauman, 2000; Bell et al., 2000; Baumgard et al., 2017). Partitioning and mobilization are directly or indirectly influenced by this adjustment. GH, insulin, IGF-1, and IR display a complex network of interactions and antagonisms, all of which are obviously related to milk production.

GH-IGF-1 axis: GH is released from the pituitary and has various effects in multiple tissues (Bartke et al., 2013). The actions of GH are mediated via growth hormone receptors (GHR), which are found in many tissues and have the highest abundance in the liver and adipose tissue (see references in Lucy et al., 2001). Transcription is mediated by three promoters in cattle resulting in GHR 1A, GHR 1B, and GHR 1C (Jiang et al., 1999). GHR 1A expression is specific for the liver and is generally regulated by development and nutrition (Lucy, 2004).

The binding of GH to GHR activates a complex signal cascade (Bartke et al., 2013), which leads, in the liver, via GHR 1A to the stimulation of IGF-1 synthesis and its release into the blood (Kobayashi et al., 1999). IGF-1 inhibits, as a feedback mechanism, the release of GH from the pituitary (Bartke et al., 2013). This GH-IGF-1 axis via GHR is inhibited by suppressors of cytokine signaling (SOCS) (Bartke et al., 2013). Furthermore, the expression of GHR 1A in the liver is increased by insulin (Butler et al., 2003; Lucy, 2004; Rhoads et al., 2004), possibly explaining the highly positive correlation between insulin and IGF-1 (Wathes et al., 2007; Fenwick et al., 2008; Cheng et al., 2015). Indeed, hyperinsulinemic-euglycemic clamp in dairy cows increases IGF-1 and reduces GH by a re-established feedback (IGF-1) and NEFA and BHB concentrations (Mashek et al., 2001).

This fine-tuning system of regulation obviously changes around parturition. During early lactation, GH in blood is augmented (Gross \& Bruckmaier, 2015), the insulin concentration is decreased (Vernon, 1989), glucose-dependent insulin release from the pancreatic islands is blunted (= IR) (Rhoads et al., 2004), and mRNA of SOCS is increased (Winkelman et al., 2008). SOCS are negative regulators of growth factor signaling (Linossi \& Nicholson, 2015), belong to insulin receptor inhibitory proteins (Haeusler et al., 2018), and might exacerbate the effects of a low insulin concentration or IR on the expression of GHR 1A. These alterations are related to lower GHR 1A expression, absent effects of GH on the liver with reduced IGF-1 release, and a diminished feedback of IGF-1 on GH discharge from the pituitary and hence to the uncoupling of the GH-IGF-1 axis with increased GH and low IGF-1 concentrations (Lucy et al., 2001; Winkelman et al., 2008). Consistent with this conclusion is the reciprocally increased mRNA expression of SOC2 and decreased mRNA expression of IGF-1 in dairy cows p.p. (Osorio et al., 2014). 
Uncoupling of the GH-IGF-1 axis: An uncoupling of the GH-IGF-1 axis in dairy cows was first suggested by Ronge and Blum (1989), because GH injection did not increase IGF-1 during early lactation. Uncoupling occurs before calving (Lucy, 2004), and some correlations have been described. The decrease in GH binding and GHR 1A mRNA coincides with a decrease of IGF-1 mRNA (Radcliff et al., 2003). Furthermore, a lower IGF-1 and higher GH in blood have been observed (Radcliff et al., 2003) suggesting a reduced feedback on GH release. The control of GHR 1A expression might be the principal mechanism of uncoupling (Radcliff et al., 2003) and partially depends on DMI (Radcliff et al., 2006), NEB (Fenwick et al., 2008), and probably on the NEFA and BHB concentration (Du et al., 2018). The authors have demonstrated in vitro that the addition of NEFA or BHB inhibits GHR 1A mRNA and markedly reduces IGF-1 mRNA expression in calf hepatocytes. This confirms the earlier observation of the strong negative correlation between mRNA GHR 1A expression and blood NEFA and BHB concentrations (Fenwick et al., 2008).

The degree of the uncoupling of the GH-IGF-1 axis seems to vary with selection for MY, because it has been observed to the same extent in two dairy breeds (Holstein and Guernsey) (Okamura et al., 2009), but not in Angus beef cattle (Jiang et al., 2005). Differences have been confirmed in a study with diverse genetic strains (HF USA versus HF NZ) and indicate a genetic effect of the degree of uncoupling of the GH-IGF-1 axis with MY (Lucy et al., 2009). Hence, "uncoupled" and high-producing cows are characterized by high GH and IR and by low insulin and IGF-1 concentrations p.p. Furthermore, low concentrations of IGF-1 in "uncoupled" Holstein cows appear to be associated with less sensitivity to IGF-1 (Mendonca et al., 2013).

The metabolic consequences of this hormonal framework have been corroborated by the studies of Gross and Bruckmaier (2015). Holstein cows were retrospectively ranked according to their highest NEFA concentrations. These cows exhibited during early lactation, in addition to high NEFA, higher BHB, lower glucose, higher GH, lower (numerical) insulin, lower IGF-1 concentrations, higher milk yield at less DMI, and consequently lower NEB. The authors relate these changes to the uncoupled GH-IGF-1 axis with the obvious consequences for mobilization and partitioning for higher MY. The changes of metabolites p.p. (NEFA $>1.2 \mathrm{mmol} \cdot \mathrm{l}^{-1}$ and BHB $>$ $1.5 \mathrm{mmol} \cdot \mathrm{l}^{-1}$ ) predispose animals to ketosis, and an uncoupled GH-IGF-1 axishas been observed in ketotic cows (Du et al., 2018) (see part II). Furthermore, the low IGF-1 concentration might promote and extend proteolysis (see above). Vice versa, the removal of metabolic load by once-a-day milking p.p. leads to higher glucose, insulin, and IGF-1 and lower NEFA and BHB concentrations in plasma and abolishes BCS loss (Kay et al., 2013).

Fibroblast growth factor 21 (FGF21) and GH-IGF-1 axis: FGF21 is a peptide hormone with systemic, paracrine, and autocrine effects and is induced in the liver of mice by starvation, a ketogenic diet, and protein deprivation (Fisher \& Maratos-Flier, 2016; Laeger et al., 2014). FGF21 is involved in the regulation of fatty acid oxidation (Fisher \& Maratos-Flier, 2016), ketogenesis, and gluconeogenesis for adaptation during starvation (De Sousa-Coelho et al., 2012), although the effect of FG21 on glucose handling is contradictory (man versus mice) (Staiger et al., 2017). Remarkably, FGF21 reduces glucose and insulin and IR in obese mice (Xu et al., 2009) and diabetic monkeys (Kharitonenkov et al., 2007), but in dairy cows, the application of FGF21 does not change blood glucose or insulin and does not act as an insulin sensitizer (Krumm et al., 2019).

However, interactions between lipid metabolism and FGF21 are also known in cattle. In the liver of cows, mRNA for FGF21 is negatively correlated with energy balance and blood glucose concentrations and is positively correlated with NEFA concentrations (Carriquiry et al., 2009). This correlation has been confirmed by Schoenberg et al. (2011). Plasma FGF21 concentration has been correlated with energy deficit, hepatic triglyceride, and NEFA. Furthermore, intralipid infusion in non-lactating non-pregnant cows increases NEFA, thereby causing a rapid increase of mRNA for FGF21 in the liver and of FGF21 concentration in blood (Caixeta et al., 2017). NEFA is obviously a potent secretagogue of FGF21 in the cow (Caixeta et al., 2017). In agreement with these data is the raised mRNA for FGF21 in dairy cows p.p. (Schlegel et al., 2013; Ha et al., 2017) and of FGF21 concentrations in plasma p.p. and during feed restriction in late-lactating cows (Schoenberg et al., 2011). Vice versa, FGF21 bolus application lowered NEFA, but this effect vanished during FGF21 infusion over 9 d (Caixeta et al., 2019). Despite this transient effect, triglyceride content in the liver was reduced by $50 \%$ (Caixeta et al., 2019).

During starvation, FGF21 has, in non-ruminants, inhibitory effects on GH in the liver and reduces the IGF-1 concentration (Inagaki et al., 2008) hinting that it has a role in GH-IGF-1 uncoupling. Dairy cows fed a.p. a high-energy diet exhibit p.p. an increased expression of FGF21 mRNA and a decrease of IGF-1 and GHR mRNA in the liver (Khan et al., 2014). "More severe NEB and NEFA results in greater hepatic FGF21", and the increase of FGF21 has been discussed as a possible reason of GH-IGF-1 uncoupling by Khan et al. (2014) and previously by Carriquiry et al. (2009). This conclusion has been confirmed by Caixeta et al. (in press). Infusion of FGF21 in 
early-lactating dairy cows reveals an antagonism of GH action. "FGF21 treated cows had lower IGF-1 despite a tendency of increased plasma GH" (Caixeta et al., 2019).

Obviously, NEFA have several effects in cows. NEFA stimulates the release of FGF21 from the liver (Caixeta et al., 2017), inhibits the expression of GHR-1A in liver cells, and mediates the uncoupling of the GH-IGF-1 axis (Du et al., 2017) (see part 2). The negative association between FGF21 and IGF-1 in a cross-sectional study of man supports this conclusion (Kralisch et al., 2013) and has been confirmed in vitro. FGF21 significantly inhibits the release of IGF-1 in a cell culture system with HepG2 cells (human liver cancer cell line) (Kralisch et al., 2013). The possible involvement of FGF21 in the regulation of lipid metabolism such as the lowering of NEFA and triglyceride in the liver of dairy cows (Caixeta et al., 2019) or the inhibition of lipolysis in rodents (Hotta et al., 2009) and the possible effect on the uncoupling of the signal cascade of the GH-GHR-IGF-1 axis warrants further research. Does FGF21 serves as a negative feedback on lipolysis?

\subsection{Protein Intake and Partitioning}

Some evidence suggests that protein influences partitioning. A protein intake increase p.p. to cover the protein requirement favors the partitioning of available nutrients toward mammary secretion during early lactation (Oldham, 1984). The partitioning effects of CP have been studied in detail by the group of Ørskov. The infusion of casein early p.p. into the abomasum increases milk production (Ørskov et al., 1977; Larsen et al., 2014) and causes, at high casein infusion, pronounced NEB and ketosis (Ørskov et al., 1987).

The response of energy balance depends on CP intake and is not observed at high metabolizable energy (ME) intake (Ørskov et al., 1981). Extending these findings, Whitelaw et al. (1986) state that "increases in MY and milk protein in response to casein will be seen only when sufficient energy is also available either from labile body stores or from dietary sources". The shift of energy from body stores into milk is obviously high in fat cows fed with high proportions of protein and a low dietary energy concentration (Jones \& Garnsworthy, 1988). However, no side effects of high CP on energy metabolism in dairy cows have been observed by Komaragiri and Erdman (1997) and Amanlou et al. (2017). Komaragiri and Erdman (1997) discuss various explanations such as the presence of enough amino acids for lipid utilization at the low crude protein intake $(16 \%)$ or the physiological limits of mobilization in high-producing cows. Obviously, the regulation of the interaction between CP intake and energy metabolism is not clear. In the short-term experiment of Oldham et al. (1978), abomasal casein infusion into Saanen goats raised the GH concentration with no significant effect on insulin or prolactin. By contrast, high casein infusion in cows leads to an increase of insulin and decrease of GH (Whitelaw et al., 1986).

\section{Synopsis of Homeorhesis: Physiological Background and Changes}

The publication of Bauman and Currie (1980) was the breakthrough for understanding the regulation of milk production and metabolism in the dairy cow p.p. The general characteristics of homeorhesis result in advantages for both the calf and its mother. The complex genetic interactions between the priority of MY, low DMI, mobilization, and partitioning secure the nutrition and protection of the calf with a marginal challenge to the metabolism or the health of the cow: An optimal biological network at low MY is shown in Figure 1. 


\section{Milk Yield, Dry Matter Intake and Energy Balance}

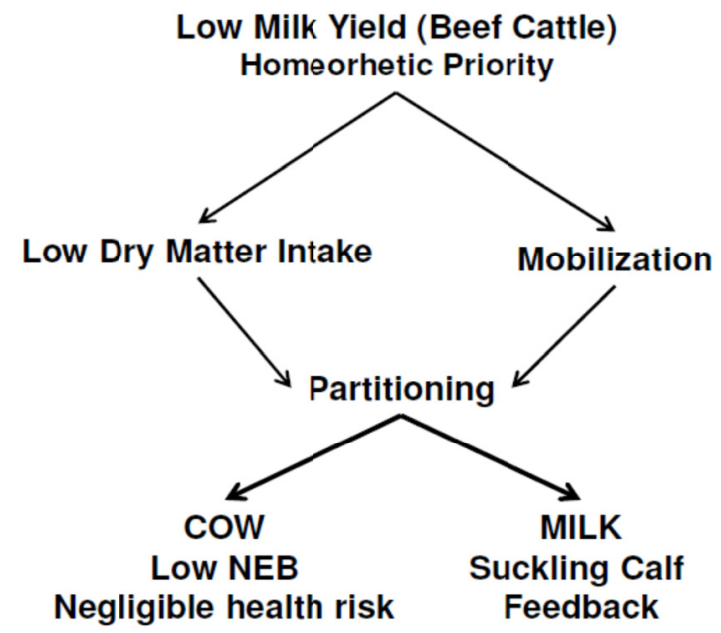

Figure 1. Scheme of network for homeorhetic regulation of milk secretion, which is genetically correlated with low DMI and with the capability of mobilization for compensating any possible gap of nutrients. At low MY (beef cattle), the interdependency between MY, DMI, mobilization, and partitioning to both milk and cow guarantees nutrition and assistance of the calf and improves its survival without a health risk for the cow. The possible NEB is of no importance

However, selection for higher MY, frequent milking, diets with high energy density, and high CP intake have increased milk production, and some of the initial optimal homeorhetic characteristics have been turned into unfavorable attributes. A major problem during early lactation is the discrepancy between the rapid increase of MY and the delay of the increase in DMI.

The insufficient DMI during early lactation (Karacaören et al., 2006; Liinamo et al., 2012; Manzilla-Pech et al., 2014; Krattenmacher et al., 2019) causes a negative genetic correlation between MY and energy balance (Spurlock et al., 2012; Brade, 2013; Krattenmacher et al., 2019) and results in the mobilization of reserves. Unsurprisingly, "it can be concluded that continued selection for high milk production will lead to a further increase in the p.p. energy deficit" (Buttchereit et al., 2011). The discrepancy between input and output was realized decades ago by Arendonk et al. (1991), and the authors proposed "an additional trait in the selection goal to avoid an increase in negative energy balance during early lactation". This confirmed the earlier observation of McNamara and Hillers (1986) that lipolysis is more pronounced in cows of high genetic merit and is independent of energy restriction p.p.; this clearly underlines the homeorhetic regulation of energy metabolism p.p. Milk production has priority over DMI with genetically driven mobilization (Friggens \& Newbold, 2007). Consequently, a "consistent correlation between (milk) yield and live-weight changes" is found (Veerkamp \& Koenen, 1999) and MY in Holstein cows "relies to a greater extent on mobilization of body reserves" (Gruber et al., 2014).

Furthermore, the partitioning of dietary energy contributes to under-nutrition. "High genetic merit animals put the extra energy from the concentrate-based diets into milk, rather than reducing the energy gap" (Agnew \& Yan, 2000; Veerkamp et al., 2003; Patton et al., 2006), an observation that agrees with that of Friggens and Newbold (2007) in Holstein Friesian cows, namely that "it is difficult to argue, given that these cows were on the same feed throughout their productive life, that intake (14 d p.p., the author) was constrained, when there was substantial energy mobilization".

Hence, under these conditions, milk production can be regarded as "a metabolic burden imposed by the synthesis and secretion of milk" (Knight et al., 1999). Taken together, the modern high-producing dairy cow p.p. is mostly characterized by,

$>$ increasing milk production with partial or total uncoupling of the GH-IGF-1 axis and less sensitivity to IGF-1,

$>$ inadequate and enduring low DMI in relation to an increased requirement for milk production and maintenance, 
$>$ mobilization of NEFA above requirement with ectopic deposition of fat,

$>$ mobilization of amino acids from protein,

$>$ preferential partitioning of metabolites, IgG, and dietary nutrient to the mammary gland,

$>$ a sudden and long-lasting NEB,

$>\quad$ at high $\mathrm{CP}$ intake, partitioning of dietary or mobilized energy to the mammary gland with potential increase of NEB,

$>$ less weight gain or possibly net loss of energy during the entire lactation period.

These unfavorable (to a certain extent) characteristics of high milk production during early lactation are furthermore regulated by homeorhesis with its high priority and lack of feedback control, irrespective of the impairment of other functions. A potential constraint of health by homeorhetic priority of milk production can easily be learnt from the pathogenesis of milk fever. $\mathrm{Ca}$ is secreted into milk even with a risk of periparturient paresis and further constraints of health. Higher milk production is associated with reduced blood $\mathrm{Ca}$ concentration at $\mathrm{d} 1$ in milk (Neves et al., 2018). Hence, the promotion of MY by breeding and management has revealed possible restrictions of health (Figure 2).

\section{Milk Yield, Dry Matter Intake and Energy Balance}

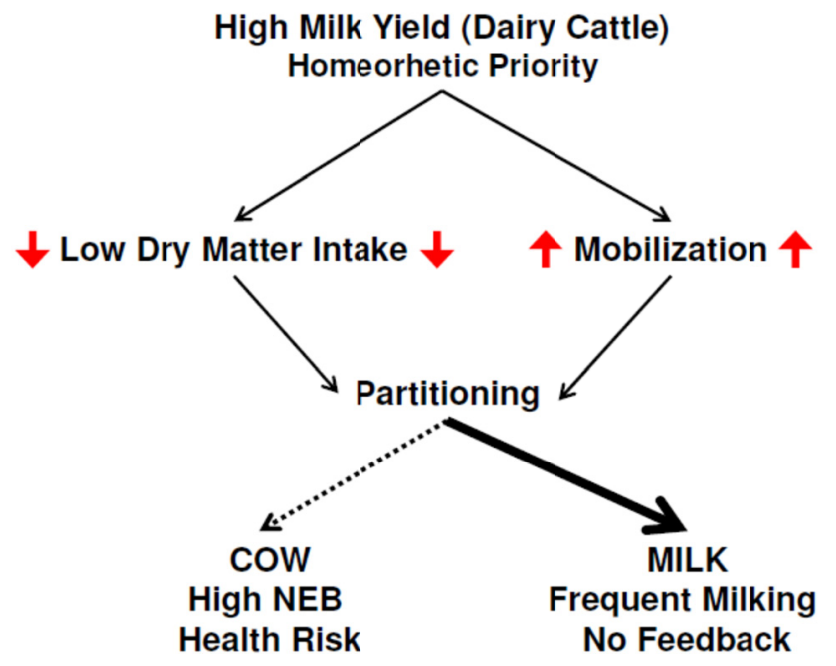

Figure 2. The well-balanced network of milk yield, DMI, mobilization, and partitioning of nutrients at low MY (Figure 1) has been disturbed by selection and management for high milk production. Milk yield is negatively genetically correlated with DMI and positively correlated with high mobilization and with the partitioning of metabolites and nutrients primarily to the mammary gland. The major consequence is an exacerbating NEB,

which is often observed before parturition. The rapid and long-lasting NEB in combination with the high metabolic rates and changes of hormones and metabolites can cause maladaptation and is a major health risk.

The arrows indicate amplification (up) or mitigation (relative decrease) (down)

One major and general shortcoming for health is the discrepancy between input and output and the resulting NEB, which simply represents under-nutrition, but concomitantly includes alterations of hormones and metabolites and a sustained increase of metabolic rate.

\section{The Negative Energy Balance: NEB}

\subsection{Past and Present}

The difference between the requirement for MY and DMI in dairy cows p.p. was mentioned many decades ago (Broster, 1972), with Bines (1976) stating: "Food intake, especially in early lactation, is a major factor limiting production from dairy cattle." Increase of MY at insufficient DMI is the major reason for NEB, although a growing body of evidence suggests that the energy requirement for maintenance has been increased in 
high-producing cows (Moares et al., 2015; Erdmann et al., 2019) and is related to the change of body composition with reduced fat and the enlarged size of metabolically active organs (Agnew \& Yan, 2000). Because Hart et al. (1975) have observed no loss of body weight (BW) p.p. in beef cattle with low MY (suckling calves), the NEB is related to MY and the higher maintenance requirement of high-producing cows.

In the 1980s, the total NEB accounted for some hundreds of $\mathrm{MJ}_{\mathrm{NEL}}$ and was apparent over a few weeks (Gravert et al., 1986; Berglund \& Danell, 1987). Since that time, the extent and duration of NEB has been increased. Tamminga et al. (1997) observed a NEB of $1284 \mathrm{MJ}_{\mathrm{NEL}}$ for 8 weeks p.p., and Sutter and Beever (2000) determined a deficit of $1786 \mathrm{MJ}$ for 8 weeks. This increase of NEB has continued: $2676 \mathrm{MJ}$ (mean) for 83 days with high variations and a much higher (maximal) NEB (Banos \& Coffey, 2009). The degree of NEB obviously and almost linearly depends on MY: $580 \mathrm{MJ}_{\mathrm{NEL}}$ at $\mathrm{MY}<25 \mathrm{~kg} / \mathrm{d}, 1323 \mathrm{MJ}_{\mathrm{NEL}}$ at $\mathrm{MY} 25-30 \mathrm{~kg} / \mathrm{d}$, and 1956 $\mathrm{MJ}_{\mathrm{NEL}}$ at MY $>30 \mathrm{~kg} / \mathrm{d}$ within 11 weeks p.p. (Brandt et al., 1985). The duration of NEB linearly increases with milk production (Steinwidder \& Gruber, 2002) and can last for $>100$ days (Bulang et al., 2006).

The NEB causes mobilization, which amounts to $41.6 \mathrm{~kg}$ empty body weight (BW) (Tamminga et al., 1997) or some $41 \mathrm{~kg} \mathrm{BW}$ (Sutter \& Beever, 2000). However, higher rates of loss of BW (114 kg in 4 weeks) have been determined by Van den Top et al. (2005) in over-conditioned cows. Most of the BW loss occurs during the first few weeks p.p. and exhibit a wide variation from calving to the nadir of BW: 0-185.1 kg (parity 1), 0-198.0 kg (parity 2), and 0-269.2 kg (parity $\geq 3$ ) (van Straten et al., 2008).

Live weight changes increase with MY with rising lactations, and the NEB is more pronounced during the $2^{\text {nd }}$ and $3^{\text {rd }}$ lactation in high genetic merit cows (Coffey et al., 2004). Further, the milk production peak is reached earlier in the $3^{\text {rd }}$ lactation without equivalent DMI (Coffey et al., 2004), and for this reason, the decline of BCS p.p. increases with increasing parity from 0.3 ( $1^{\text {st }}$ lactation) to 0.9 ( $\geq 4$ lactation; 5-point scale) (Waltner et al., 1993).

The change of BW is related to corresponding changes of body condition score (BCS). A ratio of $80-84.6 \mathrm{~kg}$ $\mathrm{BW} /$ unit BCS (5-point scale) has been discussed in the recommendations for nutrient requirements (National Research Council [NRC], 2001); a decrease of 1-unit in BCS for a cow with a BW of $650 \mathrm{~kg}$ and BCS of 4 (5 point scale) would provide $1743 \mathrm{MJ}_{\mathrm{NEL}}$ or $2126 \mathrm{MJ}$ tissue energy ( 0.82 conversion from tissue energy to $\mathrm{MJ}$ NEL) (NRC, 2001). This magnitude of MJ of $1 \triangle B C S$ is within the range of NEB in the study of Sutter and Beever (2000) but below $2676 \mathrm{MJ}$ (Banos and Coffey, 2009). At parturition, a BCS of 3.0 (5-point scale) is recommended, and cows should not lose more than 0.5 (Roche, 2006) or 0.5 to 1.0 units p.p. (Roche et al., 2009) A decline of 0.5-1.0 BCS means a loss of body weight of some 40-80 kg (NRC, 2001). Hence, the current NEB and loss of BCS probably exceeds the recommended magnitude of 0.5-1.0 BCS.

A further aspect of NEB should be discussed. It is an underlying supposition that the NEB in early lactation is compensated by body weight gain during the later lactation and dry period. "In a gross sense, intake across the whole of a lactation correlates reasonably well with output. It would be a surprise if this situation was not so" (Knight, 2001). However, Veerkamp and Koenen (1999) have stated that "selection for high milk yield results in less live-weight gain", and Coffey et al. (2004) have observed, in high genetic merit cows during 3 lactations on a low concentrate diet, a decrease of BCS of 0.54 or a loss of 1148 MJ (calculated according NRC, 2001). The calculations of Schröder and Staufenbiel (2006) indicate a loss of $1075 \mathrm{MJ}$ ( $\triangle \mathrm{BCS} 0.54=5.4 \mathrm{~mm}$ back fat thickness or $27 \mathrm{~kg}$ body fat [1 $\mathrm{kg}$ body fat $=39.8 \mathrm{MJ}]$ ).

A net loss of energy is not restricted to high-producing cows. Hurley et al. (2018) have observed, in cows in an extensive production system in Ireland (mainly grass), a strong phenotypic correlation between residual energy intake (REI) and energy balance. Hence, "animals genetically selected to have a lower REI (i.e., more efficient; the author) resulted in cows who consumed less net energy intake but were also in negative energy balance throughout the entire lactation". A continuous loss of energy and long-lasting NEB without compensation appears to be an additional health risk.

\subsection{NEB in Biology and Dairy Cows}

Periods of under-nutrition and even severe NEB occur in mammals and short or longer phases of food deprivation (adaptive fasting) are known and are related to hibernation, mating, molting, migration, or care of young (Secor \& Carey, 2016; Martinez \& Ortiz, 2017). Adaptive fasting is "an inherent survival tactic and adaptation and is distinct from starvation" (Martinez \& Ortiz, 2017) and "an innate component of many organisms" (Secor \& Carey, 2016). An example is the elephant seal, which loses some $42 \%$ of body weight after parturition during 4 weeks without feed intake (Costa et al., 1986). 
This loss is much more than that seen in dairy cows during the same time period (Tamminga et al., 1997; Sutter \& Beever, 2000), suggests a possible adaptation in dairy cows too and, at first glance, the NEB in dairy cows resembles a "physiological (biological) reaction or adaptive fasting". However, a comparison of the current NEB of the dairy cow with the biological NEB of other species appears to be questionable. First, adaptive fasting is the result of long adaptation over thousands of years of evolution. This was obviously the best strategy of survival for the relevant species. Such an adaptation appears to be unlikely in dairy cows. The current duration and extent of NEB is a result of selection for high milk production during the last $60-80$ years. Secondly, the elephant seal produces milk for only one pup. The amount of milk for one calf would hardly cause a significant NEB in cows (Hart et al., 1975). Finally, and very importantly, the milk of the elephant seal does not contain sugars (Oftedal, 1993), which are mainly produced by gluconeogenesis in the cow and are the bottle neck of metabolism for milk production and for health during early lactation (Bell, 1995). Therefore, although an allusion of NEB in biology (seal, whale) appears to be attractive (Bauman, 2000), it is probably not very helpful. Dairy cows probably do not exhibit biologically adaptive fasting, but rather the current extent and duration of NEB is an involuntary shortage, "exhibits characteristics of chronic under-nutrition" (Vernon, 1998), and cannot be classified as "natural". The present prolonged and very deep magnitude of NEB with its consequences for hormonal and metabolic changes and high metabolic rates displays symptoms of pathophysiology or insufficient adaptation.

\subsection{NEB and Adaptation of Metabolism}

The rapid increase of MY and of metabolism p.p. requires a comprehensive homeorhetic adaptation of various organ systems such as those for digestion and liver metabolism or in the mammary gland (Bauman, 2000). Adaptation of a cell, organ, or whole organism is the reaction to an internal or external stimulus (Broom, 2006). For instance, the immediate multiplication of metabolism in the dairy cow p.p. is accompanied by heat production and the possible increase of body temperature. Mechanisms are activated to dilate subcutaneous blood vessels for dissipating this heat. Body temperature is normalized, and feedback mechanisms are triggered to complete the previously activated mechanisms of heat dissipation. The organism succeeds in coping with the stimulus, and ideally, other functions are not impaired: "Coping means having control of mental and bodily stability" (Fraser \& Broom, 1990) and involves "the physiological capability to respond properly and thus maintain homeostasis" (Siegel, 1995).

The current exposure of metabolism during early lactation is a challenge for the coping and physiological capabilities and adaptation of the dairy cow. In effect, adaptation is overloaded causing metabolic disorders (see comprehensive review by Sundrum, 2015) and is a "hampered process" with impaired reproductive performance (Jorritsma et al., 2003). Insufficient adaptation coincides with the priorities of homeorhetic "milk secretion allowing them to proceed at the expense of other metabolic processes even to a point that a disease is created" (Bauman \& Currie, 1980) or "even a pathological state" (Vernon, 1998). The metabolic load during this period is a further challenge and could finally cause "metabolic stress" (Knight et al., 1999), as "that amount of metabolic load (or metabolic burden) which cannot be sustained (or tolerated), such that some energetic processes (which could include those maintaining general health) must be down regulated". A metabolic stress can easily be imagined: "For a typical dairy cow producing $40 \mathrm{~L}$ of milk/d, the metabolic energy requirements for milk production are about $200 \mathrm{MJ} / \mathrm{d}$, whereas only about $65 \mathrm{MJ} / \mathrm{d}$ is needed for maintenance. An equivalent metabolic demand for humans is running 3 marathons per day" (Sheldon et al., 2018). $40 \mathrm{~L}$ of milk/d is not the upper limit: "An early lactation cow will produce 50 to $100 \mathrm{~kg}$ of milk per day" (Lucy, 2016).

The homeorhetic priority of milk production, impaired adaptation, and metabolic stress promote restrictions of other functions, although the sequence and cause and effect are not always clear. However, the abnormal incidence of metabolic disorders during early lactation (Drackley, 1999; Ingvartsen et al., 2003; Moyes et al., 2013; Carvalho et al., 2019) and the high culling rate and number of dead cows during the first weeks p.p. (Dechow \& Goodling, 2008) before or almost parallel to the peak of lactation support the conclusion of a "pathological state": The "down regulation" of the processes "maintaining general health" causes and exacerbates health risks with fatal consequences, as shown by the increasing death rates with increasing MY (Miller et al., 2008).

\section{Conclusion}

"Milk secretion is a characteristic feature of all mammalian species" (Oftedal, 2012) and is regulated by a complex of general and specific mechanisms termed homeorhesis. This regulation includes milk secretion uncoupled from DMI, the mobilization of reserves, and the partitioning of the nutrients to the mammary gland. The appetite of the calf represents a unique combination of a feedforward stimulation of milk production by 
suckling frequency and of a feedback mechanism for limiting milk production by satiety. As a result, the demand of the growing calf is covered, and the mammary gland and metabolism of the mother are preserved, despite a small NEB. Indeed, "the success of these regulatory processes is essential to ensure the well-being of the lactating mother and survival of the nursing young" (Bauman, 2000).

Unfortunately, this balanced system has been involuntarily overlooked and unknowingly abrogated. First, milk MY has been increased over decades by intense selection for this trait and is further enhanced by frequent milking. The cutting off of the limiting feedback for MY by the uncoupling of milking from calf nutrition has exacerbated output $>>$ input. The lack of consideration of the antagonism between MY and DMI have resulted in severe and long-lasting NEB in high-producing cows with distinct alterations in their hormones and metabolites. Secondly, the gap of nutrients has been closed by the mobilization of reserves and is accompanied by an increase of NEFA concentrations in blood above the actual requirement and capacity of metabolism. NEFA causes, among other effects, IR and ectopic fat deposition, particularly in the liver with the incidence of ketosis. Thirdly, milk production with an increasing imbalance between input and output continues to have homeorhetic priority and possibly proceeds at the expensive of other functions with a subsequent impairment of health. Hence, optimal MY for calf nutrition has been replaced by maximal milk production for economic reasons with evidence of critical off-target effects and with the down regulation of the processes maintaining general health. The unintended consequences of high MY $(\approx \mathrm{NEB})$ are obvious maladaptation, metabolic stress, and indeed health risks. These health risks have clearly been expressed by Lucy (2016): "Unfortunately, years of genetic selection for milk production without consideration of other traits lead to problems in health, reproduction and longevity in modern dairy cows." (see part 2).

\section{Acknowledgements}

The study was supported by the Margarete-Markus-Charity and the Bundesministerium für Bildung, Wissenschaft und Forschung. The author wish to acknowledge with gratitude the reading and suggestions of W. Brade, H. Bostedt, L. Gruber and S. Leonhard-Marek.

\section{References}

Agnew, R., \& Yan, T. (2000). Impact of recent research on energy feeding system for dairy cattle. Livestock Production Science, 66, 197-215. https://doi.org/10.1016/S0301-6226(00)00161-5

Akamatsu, H., Saitoh, Y., Serizawa, M., Miyake, K., Ohba, Y., \& Nakashima, K. (2007). Changes of serum 3-methylhistidine concentration and energy-associated metabolites in dairy cows with ketosis. Journal of Veterinary Medical Science, 69, 1091-1093. https://doi.org/10.1292/jvms.69.1091

Aleri, J., Hine, B., Pyman, M., Mansell, P., Wales, W., Mallard, B., \& Fisher, A. (2016). Periparturient immunosuppression and strategies to improve dairy cow health during the periparturient period. Research in Veterinary Science, 108, 8-17. https://doi.org/10.1016/j.rvsc.2016.07.007

Allen, M. (2000). Effects of diet on short-term regulation of feed intake by lactating dairy cattle. Journal of Dairy Science, 83, 1598-1624. https://doi.org/10.3168/jds.S0022-0302(00)75030-2

Allen, M., \& Bradford, B. (2012). Control of food intake by fuels: A comparison across species. Proceedings of the Nutrition Society, 71, 401-409. https://doi.org/10.1017/S0029665112000572

Allen, M., \& Piantoni, P. (2013). Metabolic control of feed intake. Implications for metabolic diseases of fresh cows. Veterinary Clinics of North America: Food Animal Practice, 29, 279-297. https://doi.org/10.1016/ j.cvfa. 2013. 04.001

Amanlou, H., Farhani, T., \& Farsuni, N. (2017). Effects of rumen undegradable protein supplementation on productive performance and indicators of protein and energy metabolism in Holstein fresh cows. Journal of Dairy Science, 100, 3628-3640. https://doi.org/10.3168/jds.2016-11794

Andersen, J., Friggens, N., Serjen, K., Soerensen, T., Munskaard, L., \& Invartsen, K. (2003). The effects of low vs. high concentrate level in the diet on performance in cows milked two or three times daily in early lactation. Livestock Production Science, 81, 119-128. https://doi.org/10.1016/S0301-6226(02)00303-2

Arendonk, J., Nieuwhof, G., Vos, H., \& Korver, S. (1991). Genetic aspects of feed intake and efficiency in lactating dairy heifers. Livestock Production Science, 29, 263-275. https://doi.org/10.1016/0301-6226 (91)90103-W

Banos, G., \& Coffey, M. (2009). Genetic association between body energy measured throughout lactation and fertility in cattle. Animal, 4, 189-199.https://doi.org/10.3168/jds.2009-2613 
Bar-Peled, U., Aharoni, Y., Robinson, B., Bruckental, I., Lehrer, R., Maltz, E., \& Tagari, H. (1998). The effect of enhanced milk yield of dairy cows by frequent milking or suckling on intake and digestibility of the diet. Journal of Dairy Science, 81, 1420-1427. https://doi.org/10.3168/jds.S0022-0302(98)75706-6

Bartke, A., Sun, L., \& Longo, V. (2013). Somatotropic signaling: Trade-offs between growth, reproductive development, and longevity. Physiological Reviews, 93, 571-598. https://doi.org/10.1152/physrev. 00006.2012

Bauman, D. (1999). Bovine Somatotropin and lactation: from basic science to commercial application. Domestic Animal Endocrinology, 17, 101-115. https://doi.org/10.1016/s0739-7240(99)00028-4

Bauman, D. (2000). Regulation of nutrient portioning during lactation: Homeostasis and homeorhesis revisited. In P. Cronjé (Ed.), Ruminant Physiology: Digestion, Metabolism, Growth and Reproduction (pp. 311-328). CAB International. https://doi.org/10.1079/9780851994635.0311

Bauman, D., \& Currie, E. (1980). Partitioning of nutrients during pregnancy and lactation. Journal of Dairy Science, 63, 1514-1529.https://doi.org/10.3168/jds.s0022-0302(80)83111-0

Bauman, D., Peel, C., Steinhour, W., Reynolds, P., Tyrell, H., Brown, A., \& Haaland, G. (1988). Effect of bovine somatotropin on metabolism of lactating dairy cows: Influence on rates of irreversible loss and oxidation of glucose and nonesterified fat acids. Journal of Nutrition, 118, 1031-1040. https://doi.org/10.1093/jn/ 118.8.1031

Baumgard, L., Collier, R., \& Bauman, D. (2017). A 100-Year Review: Regulation of nutrient partitioning to support lactation. Journal of Dairy Science, 100, 10352-10366. https://doi.org/10.3168/jds.2017-13242

Bell, A. (1995). Regulation of organic nutrients metabolism during transition from late pregnancy to early lactation. Journal of Animal Science, 73, 2804-2819. https://doi.org/10.3168/jds.2017-13242

Bell, A., \& Bauman, D. (1997). Adaptation of glucose metabolism during pregnancy and lactation. Journal of Mammary Gland Biology and Neoplasia, 2, 265-278. https://doi.org/10.1023/a:1026336505343

Bell, A., Bauman, D., \& Currie, B. (1987). Regulation of nutrient partitioning and metabolism during pre- and postnatal growth. Journal of Animal Science, 65(Suppl. 2), 186-212. https://doi.org/10.1093/ansci/ 65.suppl_2.186

Bell, A., Burhans, W., \& Overton, T. (2000). Protein nutrition in late pregnancy, maternal reserves and lactation performance in dairy cows. Proceedings of the Nutrition Society, 59, 199-226. https://doi.org/10.1017/ s002966510000 0148

Berglund, B., \& Danell, B. (1987). Live weight changes, feed consumption, milk yield and energy balance in dairy cattle during first period of lactation. Acta Agriculturae Scandinavica, 37, 495-509. https://doi.org/ $10.1080 / 00015128709436581$

Bertics, S., Grummer, R., Cadorniga-Valino, C., \& Stoddard, E. (1992). Effect of prepartum dry matter intake on liver triglyceride concentration and early lactation. Journal of Dairy Science, 75, 1914-1922. https://doi.org/ 10.3168/jds.S0022-0302(92)77951-X

Bines, J. (1976). Regulation of food intake in dairy cows in relation to milk production. Livestock Production Science, 3, 115-128. https://doi.org/10.1016/0301-6226(76)90029-4

Boisclair, Y., Wesolowski, S., Kim, J., \& Ehrhardt, R. (2006). Roles of growth hormone and leptin in the periparturient dairy cow. In K. Sejrsen, T. Hvelplung, \& M. Nielsen (Eds.), Ruminant Physiology. Digestion metabolism and impact of nutrition on gene expression, immunology and stress (pp. 327-344). Wageningen Academic Publishers.

Brade, W. (2013). Die Energiebilanz hoch leistender Milchkühe aus der Sicht der Züchtung und des Tierschutzes. Praktischer Tierarzt, 94, 536-544.

Brandt, A., Pabst, K., Schulte-Coerne, H., \& Gravert, H. (1985). Die Heritabilität der Futteraufnahme. Züchtungskunde, 57, 299-308.

Broom, D. (2006). Adaptation. Berliner und Münchener Tierärztliche Wochenschrift, 119, 1-6.

Broster, W. (1972). Effect on milk yield of the cow of the level of feeding during lactation. Dairy Science Abstracts, 24, 265-288.

BRS (Bundesverband Rind und Schwein). (2018). Rinderproduktion in Deutschland 3017-Ausgabe 2018. Bonn, Germany. 
Bulang, M., Kluth, H., Engelhard, T., Spilke, J., \& Rodehutscord, M. (2006). Studies on the use of lucerne silage source for high-milk-producing dairy cows. Journal of Animal Physiology and Animal Nutrition, 90, 89-102. https://doi.org/10.1111/j.1439-0396.2005.00568.x

Butler, S., Marr, A., Pelton, S., Radcliff, S., Lucy, M., \& Butler, R. (2003). Insulin restores GH responsiveness during lactation-induced negative energy balance in dairy cattle: effects on expression of IGF-I and GH receptor 1A. Journal of Endocrinology, 176, 205-217. https://doi.org/10.1677/joe.0.1760205

Buttchereit, N., Stamer, E., Junge, W., \& Thaller, G. (2011). Short communication: Genetic relationship among daily energy balance, feed intake, body condition score, and fat to protein ratio of milk in dairy cows. Journal of Dairy Science, 94, 1586-1591. https://doi.org/10.3168/jds.2010-3396

Caixeta, L., Giesy, S., Krumm, C., Perfield, J., Butterfield, A., Schoenberg, K., \& Boisclair, Y. (2017). Effect of circulating glucagon and free fatty acids on hepatic FGF21 production in dairy cows. American Journal of Physiology. Regulatory, Integrative and Comparative Physiology, 313, R526-R534. https://oi.org/10.1152/ ajpregu.00197.2017

Caixeta, L., Giesy, S., Krumm, C., Perfield, J., Butterfield, A., \& Boisclair, Y. (2019). Fibroblast growth factor-21 (FGF21) administration to early-lactating dairy cows. II. Pharmacokinetics, whole-animal performance, and lipid metabolism. Journal of Dairy Science, 102, 11597-11608. https://doi.org/10.3168/ jds.2019-16696

Cameron, R., Dyk, P., Herdt, T., Kaneene, J., Miller, R., Bucholtz, H., \& Emery, R. (1998). Dry cow diet, management, and energy balance as risk factors for displaced abomasum in high producing dairy herds. Journal of Dairy Science, 81, 132-139. https://doi.org/10.3168/jds.S0022-0302(98)75560-2

Carriquiry, M., Weber, W. J., Fahrenkrug, S., \& Crooker, B. (2009). Hepatic gene expression in multiparous Holstein cows treated with bovine somatotropin and fed n-3 fatty acids in early lactation. Journal of Dairy Science, 92, 4889-4900. https://doi.org/10.3168/jds.2008-1676

Carvalho, M., Penagaricano, F., Santos, J., DeVries, T., McBride, B., \& Ribeiro, E. (2019). Long-term effects of postpartum clinical diseases on milk production, reproduction, and culling of dairy cows. Journal of Dairy Science, 102, 11701-1117. https://doi.org/10.3168/jds.2019-17025

Cheng, Z., Oguejiofor, C., Swangchan-Uthai, T., Carr, S., \& Wathes, D. (2015). Relationship between circulating urea concentrations and endometrial function in postpartum dairy cows. Animals, 5, 748-773. https://doi.org/ 10.3390/ani5030382

Chilliard, Y., Bocquier, F., \& Doreau, M. (1998). Digestive and metabolic adaptations of ruminants to under-nutrition, and consequences on reproduction. Reproduction Nutrition Development, 38, 131-152. https://doi.org/10.1051/rnd:19980201

Coffey, M., Simm, G., Oldham, J., Hill, W., \& Brotherstone, S. (2004). Genotype and diet effect on energy balance in the first three lactations of dairy cows. Journal of Dairy Science, 87, 4318-4326. https://doi.org/ 10.3168/jds.S0022-0302(04)73577-8

Collier, R., \& Bauman, D. (2017). Triennial Lactation Symposium/BOLFA: Historical perspectives of lactation biology in the late $20^{\text {th }}$ and early $21^{\text {st }}$ centuries. Journal of Animal Science, 95, 5639-5682. https://doi.org/ $10.2527 /$ jas2017.1875

Contreras, G., Strieder-Barboza, C., \& Raphael, W. (2017). Adipose tissue lipolysis and remodeling during transition period of dairy cows. Journal of Animal Science and Biotechnology, 8, 41. https://doi.org/ 10.1186/s40104-017-0174-4

Costa, D., LeBoeuf, B., Ortiz, C., \& Huntley, A. (1986). The energetics of lactation in the northern elephant seal Mirounga angustirostris. Journal of Zoology, 209, 21-33. https://doi.org/10.1111/j.1469-7998.1986. tb03563.x

Dann, H., Litherland, N., Underwood, J., Bionaz, M., D’Angelo, A., McFadden, J., \& Drackley, J. (2006). Diets during far-off and close-up dry periods affect periparturient metabolism and lactation in multiparous cows. Journal of Dairy Science, 89, 3563-3577. https://doi.org/10.3168/jds.S0022-0302(06)72396-7

De Koster, J. D., \& Opsomer, G. (2013). Insulin resistance in dairy cattle. Veterinary Clinics of North America: Food Animal Practice, 29, 299-322. https://doi.org/10.1016/j.cvfa.2013.04.002 
De Sousa-Coelho, A., Marrero, P., \& Haro, D. (2012). Activating transcription factor 4-dependent induction of FGF21 during amino acid deprivation. Biochemical Journal, 443, 165-171. https://oi.org/10.1042/ BJ20111748

Dechow, C., \& Goodling, R. (2008). Mortality, culling by sixty days in milk, and production profiles in highand low-survival Pennsylvania herds. Journal of Dairy Science, 91, 4630-4639. https://doi.org/10.3168/ jds.2008-1337

Deutsch Holstein. (2017). Retrieved from http://www.holstein-dhv.de/seiteninhalte/zuchtwert schaetzung.html

Drackley, J. (1999). ADSA Foundation Scholar Award. Biology of dairy cows during the transition period: The final frontier. Journal of Dairy Science, 82, 2259-2273. https://doi.org/10.3168/jds.s0022-0302(99)75474-3

Du, X., Zhu, Y., Peng, Z., Cui, Y., Zhang, Q., Shi, Z., \& Liu, G. (2018). High concentrations of fat acids and $\beta$-hydroxybutyrate impair the growth hormone-mediated hepatic JAK2-STAT5 pathway in clinically ketotic cows. Journal of Dairy Science, 101, 3476-3487. https://doi.org/10.3168/jds.2017-13234

Eastridge, M. (2006). Major advances in applied dairy cattle nutrition. Journal of Dairy Science, 89, 1311-1323. https://doi.org/10.3168/jds.S0022-0302(06)72199-3

Eger, M., Horn, J., Hussen, J., Schuberth, H.-J., Scharf, M., Meyer, U., \& Breves, G. (2017). Effects of dietary CLA supplementation, parity and different concentrate levels before calving on immunoglobulin G1, G2 and $\mathrm{M}$ concentrations in dairy cows. Research in Veterinary Science, 114, 287-293. https://doi.org/ 10.1016/j.rvsc.2017.05.026

Erdmann, S., Derno, M., Schäff, C., Börner, S., Kautzsch, U., Kuhla, B., \& Röntgen, M. (2019). Comparative analyses of estimated and calorimetrically determined energy balance in high-yielding dairy cows. Journal of Dairy Science, 102, 4002-4013. https://doi.org/10.3168/jds.2018-15017

Etherton, T. (1982). The role of insulin-receptor interactions in regulation of nutrient utilization by skeletal muscle and adipose tissue: A review. Journal of Animal Science, 54, 58-67. https://oi.org/10.2527/ jas1982.54158x

Etherton, T., \& Bauman, D. (1998). Biology of somatotropin in growth and lactation of domestic animals. Physiological Reviews, 78, 745-761. https://doi.org/10.1152/physrev.1998.78.3.745

Farney, J., Mamedova, L., Coetzee, J., KuKanich, B., Sordillo, L., Stoakes, S., \& Bradford, B. (2013). Anti-inflammatory salicylate treatment alters the metabolic adaptations to lactation in dairy cattle. American Journal of Physiology. Regulatory, Integrative and Comparative Physiology, 305, R110-117. https://doi.org/ 10.1152/ajpregu.00152.2013

Faverdin, P., Dulphy, J., Coulon, J., Vérite, R., Garel, J., Rouel, J., \& Marquis, B. (1991). Substitution of roughage by concentrates of dairy cows. Livestock Production Science, 27, 137-151. https://doi.org/ 10.1016/0301-6226(91)90092-5

Fenwick, M., Fitzpatrick, R., Kenny, D., Diskin, J., Murphy, J., \& Wathes, D. (2008). Interrelationships between negative energy balance (NEB) and IGF regulation in liver of lactating cows. Domestic Animal Endocrinology, 34, 31-44. https://doi.org/10.1016/j.domaniend.2006.10.002

Finn, P., \& Dice, J. (2005). Ketone bodies stimulate chaperone-mediated autophagy. Journal of Biological Chemistry, 280, 25864-25870. https://doi.org/10.1074/jbc.M502456200

Fisher, M., \& Maratos-Flier, E. (2016). Understanding the physiology of FGF21. Annual Review of Physiology, 78, 223-241. https://doi.org/10.1146/annurev-physiol-021115-105339

Fraser, A., \& Broom, D. (1990). Farm Animal and Welfare. Wallingford: C.A.B.I.

Friggens, N., \& Newbold, J. (2007). Towards a biological basis for prediction nutrient partitioning: The dairy cow as an example. Animal, 1,87-97. https://doi.org/10.1017/S1751731107657772

Friggens, N., Berg, P., Theilgaard, P., Korsgaard, I., Ingartsen, K., LØvendahl, P., \& Jensen, J. (2007). Breed and parity effects on energy balance profiles through lactation: Evidence of genetically driven body energy change. Journal of Dairy Science, 90, 5291-5305. https://doi.org/10.3168/jds.2007-0173

GfE (Gesellschaft für Ernährungsphysiologie). (2001). In G. Flachowsky, H. Jeroch, M. Kirchgeßner, J. Pallauf, E. Pfeffer, E. Schulz, \& W. Staudacher (Eds.), Empfehlungen zur Energie- und Nährstoffversorgung der Milchkühe und Aufzuchtrinder. DLG Verlag Frankfurt, Germany. 
Gravert, H. (1985). Genetic factors controlling feed intake efficiency in dairy cows. Livestock Production Science, 13, 87-95. https://doi.org/10.1016/0301-6226(85)90013-2

Gravert, H., Langner, R., Diekmann, L., Pabst, L., \& Schulte-Coerne, H. (1986). Ketokörper in Milch als Indikatoren für die Energiebilanz der Milchkühe. Züchtungskunde, 58, 309-318.

Gross, J., \& Bruckmaier, R. (2015). Repeatability of metabolic responses to a nutrient deficiency in early and mid lactation and implications for robustness of dairy cows. Journal of Dairy Science, 98, 8634-8643. https://doi.org/10.3168/jds.2014-9246

Gruber, L., Pries, M., Schwarz, F.-J., Spiekers, H., \& Staudacher, W. (2006). DLG-Information (Issue 1, pp. 2-29). Retrieved from http://www.dlg.org/fachinfos-rinder.htm

Gruber, L., Urdl, M., Obritzhauser, W., Schauer, A., Häusler, J., \& Steiner, B. (2014). Influence of energy and nutrient supply pre and post partum on performance of multiparous Simmental, Brown Swiss and Holstein cows in early lactation. Animal, 8, 58-71. https://doi.org/10.1017/S1751731113001894

Grummer, R. (1995). Impact of changes in organic nutrient metabolism on feeding in transition dairy cow. Journal of Animal Science, 73, 2820-2833. https://doi.org/10.2527/1995.7392820x

Grummer, R., Mashe, G., \& Hayirli, A. (2004). Dry matter intake and energy balance in the transition period. Veterinary Clinics of North America: Food Animal Practice, 20, 447-470. https://doi.org/10.1016/j.cvfa. 2004.06.013

Gualdrón-Duarte, L., \& Allen, M. (2017). Increased anaplerosis of the tricarboxylic acid circle decreased meal size and energy intake of cows in the postpartum period. Journal of Dairy Science, 100, 4425-4434. https://doi.org/10.3168/jds.2016-12104

Ha, N.-T., Drögemüller, C., Reimer, C., Schmitz-Hsu, F., Bruckmaier, R., Simianer, H., \& Gross, J. (2017). Liver transcriptome analysis reveals important factors involved in the metabolic adaptation of the transition cow. Journal of Dairy Science, 100, 9311-9323. https://doi.org/10.3168/jds.2016-12454

Haeusler, R., McGraw, T., \& Accili, D. (2018). Biochemical and cellular properties of insulin receptor signalling. Nature Reviews Molecular Cell Biology, 19, 31-44. https://doi.org/10.1038/nrm.2017.89

Hansen, L. (2000). Consequences of Selection for milk yield from a geneticist's viewpoint. Journal of Dairy Science, 83, 1145-1150. https://doi.org/10.3168/jds.S0022-0302(00)74980-0

Hart, I., Bines, J., Balch, C., \& Cowie, A. (1975). Hormone and metabolic differences between lactating beef and dairy cattle. Life Sciences, 16, 1285-1292. https://doi.org/10.1016/0024-3205(75)90313-6

Hart, I., Bines, J., Morant, S., \& Ridley, J. (1978). Endocrine control of energy metabolism in the cow: comparison of the levels of hormones (prolactin, growth hormone, insulin and thyroxine) and metabolites in the plasma of high- and low-yielding cattle at various stages of lactation. Journal of Endocrinology, 77, 333-345. https://doi.org/10.1677/joe.0.0770333

Heine, M., Fischer, A., Schlein, C., Jung, C., Straub, L., Gottschling, K., \& Heeren, J. (2018). Lipolysis triggers a systemic insulin response essential for efficient energy replenishment of activated brown adipose tissue in mice. Cell Metabolism, 28, 644-655. https://doi.org/10.1016/j.cmet.2018.06.020

Herdt, T. (2000). Ruminant adaptation to negative energy balance. Influences on the aetiology of ketosis and fat liver. Veterinary Clinics of North America: Food Animal Practice, 16, 215-230. https://doi.org/10.1016/ S0749-0720(15)30102-X

Herr, M., Bostedt, H., \& Failing, K. (2011). IgG and IgM levels in dairy cows during the periparturient period. Theriogenology, 75, 377-385. https://doi.org/10.1016/j.theriogenology.2010.09.009

Horino, M., Machlin, L. J., Hertelendy, F., \& Kipnis, D. (1968). Effect of short-chain fatty acids on plasma insulin in ruminant and nonruminant species. Endocrinology, 83, 118-128. https://doi.org/10.1210/ endo-83-1-118

Horst, W., Kvidera, S., Mayorga, E., Shouse, C., Al-Qaisi, M., Dickson, M., \& Baumgard, L. (2018). Effect of chromium on bioenergetics and leukocyte dynamics following immunoactivation in lactating Holstein cows. Journal of Dairy Science, 101, 5515-5530. https://doi.org/10.3168/jds.2017-13899

Hotta, Y., Nakamura, H., Komishi, M., Murata, Y., Takagi, H., Matsumura, S., \& Itoh, N. (2009). Fibroblast growth factor 21 regulates lipolysis in white adipose tissue but is not required for ketogenesis and triglyceride clearance in liver. Endocrinology, 150, 4625-4633. https://doi.org/10.1210/en.2009-0119 
Hurley, A., Lopez-Villabos, N., McParland, S., Lewis, E., Kennedy, E., O’Donovan, M., \& Berry, D. (2018). Characteristics of feed efficiency within and across lactation in dairy cows and the effect of genetic selection. Journal of Dairy Science, 101, 1267-1280. https://doi.org/10.3168/jds.2017-12841

Hüttmann, H., Stamer, E., Junge, W., Thaller, G., \& Kalm, E. (2009). Analysis of feed intake and energy balance of high-yielding first lactation cows with fixed and random regression models. Animal, 3, 181-188. https://doi.org/10.1017/S175173110800325X

Inagaki, T., Lin, V., Goetz, R., Mohammadi, M., Mangelsdorf, D., \& Kliewer, S. (2008). Inhibition of growth hormone signaling by the fasting-induced hormone FGF21. Cell Metabolism, 8, 77-83. https://doi.org/ 10.1016/j.cmet.2008.05.006

Ingvartsen, K., \& Andersen, J. (2000). Integration of metabolism and intake regulation: A review focusing on periparturient animals. Journal of Dairy Science, 83, 1573-1597. https://doi.org/10.3168/jds.S0022-0302 (00)75029-6

Ingvartsen, K., Dewhorst, R., \& Friggens, N. (2003). On the relationship between lactational performance and health: is it yield or metabolic imbalance that causes production diseases in dairy cattle? A position paper. Livestock Production Science, 83, 277-330. https://doi.org/10.1016/S0301-6226(03)00110-6

Israeli Dairy Board. (2017). The profitability of the Israeli dairy cattle branch in 2016. Israeli Dairy Board, Yahud, Israel. Retrieved from https://www.fil-idf.org/nationalcommittees/israel-dairy-board/

Jensen, L., Nielsen, N., Nadeau, E., Markussen, B., \& Nørgaard, P. (2015). Evaluation of five models predicting feed intake by dairy cows fed total mixed rations. Livestock Science, 176, 91-103. https://doi.org/10.1016/ j.livsci.2015.03.026

Jiang, H., Lucy, M., Crooker, B., \& Beal, W. (2005). Expression of growth hormone Receptor 1A mRNA is decreased in dairy cows but not in beef cows at parturition. Journal of Dairy Science, 88, 1370-1377. https://doi.org/10.3168/jds.S0022-0302(05)72804-6

Jiang, H., Okamura, C., \& Lucy, M. (1999). Isolation and characterization of a novel promoter for the bovine growth hormone receptor gene. Journal of Biological Chemistry, 274, 7893-7900. https://doi.org/10.1074/ jbc.274.12.7893

Jones, G., \& Garnsworthy, P. (1988). The effects of body condition at calving and dietary protein content on dry-matter intake and performance in dairy cows given diets at low energy content. Animal Production, 47, 321-333. https://doi.org/10.1017/S0003356100003457

Jorritsam, R., Wensing, T., Kruip, T., Vos, P., \& Noordhuizen, F. (2003). Metabolic changes in early lactation and impaired reproductive performance in cows. Veterinary Journal, 34, 11-26. https://doi.org/10.1051/ vetres:20022054

Karacaören, B., Jaffrézi, F., \& Kadarmideen, H. (2006). Genetic parameters for functional traits in dairy cattle from random regression models. Journal Dairy Science, 89, 791-798. https://doi.org/10.3168/jds. S0022-0302(06)72141-5

Kay, J., Phyn, C., Rius, A., Morgan, S., Grala, T., \& Roche, J. (2013). Once-daily milking during a feed deficit decreases milk production but improves energy status in early lactating grazing dairy cows. Journal of Dairy Science, 96, 6274-6284. https://doi.org/10.3168/jds.2012-6167

Khan, M., Jacometo, C., Graugnard, D., Corrêa, M., Schmitt, E., Cardoso, F., \& Loor, J. (2014). Overfeeding dairy cattle during late-pregnancy alters hepatic PPAR $\alpha$-regulated pathways including hepatokines: Impact on metabolism and peripheral insulin sensitivity. Gene Regulation and Systems Biology, 8, 97-111. https://doi.org/10.4137/GRSB.S14116

Kharitonenkov, A., Wroblewski, V., Koester, A., Chen, Y.-F., Clutinger, C., Tigno, X., \& Etgen, G. (2007). The metabolic state of diabetic monkeys is regulated by fibroblast growth factor-21. Endocrinology, 148, 774-781. https://doi.org/10.1210/en.2006-1168

Knight, C. (2001). Lactation and gestation in dairy cows: Flexibility avoids nutritional extremes. Proceedings of the Nutrition Society, 60, 527-537. https://doi.org/10.1079/PNS2001115

Knight, C., Beever, D., \& Sorensen, A. (1999). Metabolic loads to be expected from different genotypes under different systems. In J. Oldham, G. Simm, A. Groen, B. Nielsen, J. Pryce, \& T. Lawrence (Eds.), Metabolic stress in dairy cows. British Society of Animal Science Occasional Publication (No. 24, pp. 27-35). Pencuit, Midlothian: British Society of Animal Science. https://doi.org/10.1017/S1463981500043053 
Kobayashi, Y., Boyd, C., Bracken, C., Lamberson, W., Keisler, D., \& Lucy, M. (1999). Reduced growth hormone receptor (GHR) messenger ribonucleic acid in liver of periparturient cattle is caused by a specific down-regulation of GHR 1A that is associated with decreased insulin-like growth factor I. Endocrinology, 140, 3947-3954. https://doi.org/10.1210/endo.140.9.7000

Komaragiri, M., \& Erdman, R. (1997). Factors affecting body tissue mobilization in early lactation dairy cows. 1. Effect of dietary protein on mobilization of body fat and protein. Journal of Dairy Science, 80, 929-937. https://doi.org/10.3168/jds.S0022-0302(97)76016-8

Kralisch, S., Tönjes, A., Krause, K., Richter, J., Lossner, U., Kovacs, P., \& Fasshauer, M. (2013). Fibroblast growth factor-21 serum concentrations are associated with metabolic and hepatic markers in humans. Journal of Endocrinology, 216, 135-143. https://doi.org/10.1530/JOE-12-0367

Krattenmacher, N., Thaller, G., \& Tetens, J. (2019). Analysis of the genetic architecture of energy balance and its major determinants dry matter intake and energy-corrected milk yield in primiparous Holstein cows. Journal of Dairy Science, 102, 3241-3253. https://doi.org/10.3168/jds.2018-15480

Krumm, C., Giesy, S., Caixeta, L., Perfield, J., Sauerwein, H., Moore, B., \& Boisclair, Y. (2019). Fibroblast growth factor-21 (FGF21) administration to early-lactating dairy cows. I. Effects of signaling and indices of insulin action. Journal of Dairy Science, 102, 11597-11608. https://doi.org/10.3168/jds.2019-16696

Kuhla, B., Metges, C., \& Hammon, H. (2016). Endogenous and dietary lipids influencing feed intake and energy metabolism of periparturient dairy cows. Domestic Animal Endocrinololy, 56(Suppl.), S2-S10. https://doi.org/10.1016/j.domaniend.2015.12.002

Kvidera, S., Horst, E., Abuajamieh, M., Mayorga, E., Sanz Fernandez, M., \& Baumgard, L. (2017). Glucose requirements of activated immune system in lactating Holstein cows. Journal of Dairy Science, 100, 2360-2374. https://doi.org/10.2527/jas2017.1830

Laeger, T., Henagan, T., Albarado, D., Redman, L., Bray, G., Noland, R., \& Morrison, C. (2014). FGF21 is an endocrine signal of protein restriction. Journal of Clinical Investigation, 124, 3913-3922. https://doi.org/ 10.1172/JCI74915

Laeger, T., Sauerwein, H., Tuchscherer, A., Bellmann, O., Metges, C., \& Kuhla, B. (2013). Concentrations of hormones and metabolites in cerebrospinal fluid and plasma of dairy cows during the periparturient period. Journal of Dairy Science, 96, 2883-2893. https://doi.org/10.3168/jds.2012-5909

Larsen, M., Lapierre, H., \& Kristensen, N. (2014). Abomasal protein infusion in postpartum cows: Effect on performance and mammary metabolism. Journal of Dairy Science, 97, 5608-5622. https://doi.org/10.3168/ jds.2013-7247

Lean, I., Farver, T., Troutt, H., Bruss, M., Galland, J., Baldwin, R., \& Weaver, L. (1992). Time series cross-correlation analysis of postparturient relationships among serum metabolites and yield variables in Holstein cows. Journal of Dairy Science, 75, 1891-1900.https://doi.org/10.3168/jds.S0022-0302(92) 77949-1

Liinamo, A., Mäntysaari, P., \& Mäntysaari, E. (2012). Short communication: Genetic parameters for feed intake, production, and extent of negative energy balance in Nordic Red dairy cattle. Journal of Dairy Science, 95, 6788-6794. https://doi.org/10.3168/jds.2012-5342

Linossi, E., \& Nicholson, S. (2015). Kinase inhibition, competitive binding and proteasomal degradation: resolving the molecular function of the suppressor of cytokine signaling (SOCS) proteins. Immunological Reviews, 266, 123-133. https://doi.org/10.1111/imr.12305

Lucy, M. (2004). Mechanisms linking the somatotropic axis with insulin: Lessons from the postpartum dairy cow. New Zealand Society of Animal Production, 64, 19-23.

Lucy, M. (2016). Mechanisms linking prepartum metabolism with reproduction. WCDS Advances in Dairy Technology, 28, 250-269.

Lucy, M., Jiang, H., \& Kobayashi, Y. (2001). Changes in the somatotropic axis associated with the initiation of lactation. Journal of Dairy Science, 84(Suppl.), E113-E119. https://doi.org/10.3168/jds.S0022-0302 (01)70205-6Lucy, M., Verkerk, G., Whyte, B., Macdonald, K., Burton, L., Cursons, R., \& Holmes, C. (2009). Somatropic axis components and nutrient partitioning in genetically diverse dairy cows management under different feed allowances in a pasture system. Journal of Dairy Science, 92, 526-539. https://doi.org/10.3168/ jds.2008-1421 
Mahrt, A., Burfeind, O., \& Heuwieser, W. (2015). Evaluation of hyperketonemia risk period and screening of early-lactation dairy cows. Journal of Dairy Science, 98, 3110-3119. https://doi.org/10.3168/jds.2014-8910

Mann, S., Abuelo, A., Nydam, D., Leal Yepes, F., Overton, T., \& Wakshlag, J. (2016). Insulin signaling and skeletal muscle atrophy and autophagy in transition cows either overfed energy or fed a control energy diet prepartum. Journal of Comparative Physiology B, 186, 513-525. https://doi.org/10.1007/s00360-0160969-1

Manzanilla-Pech, M., Veerkamp, R., Calus, M., Zom, R., van Knegsel, A., Pryce, A., \& De Haas, Y. (2014). Genetic parameters across lactation for feed intake, fat- and protein-corrected milk, and live weight in first-parity Holstein cattle. Journal of Dairy Science, 97, 5851-5862. https://doi.org/10.3168/jds.2014-8165

Martinez, B., \& Ortiz, R. (2017). Thyroid hormone regulation and insulin resistance: Insights from animals naturally adapted to fasting. Physiology, 32, 141-151. https://doi.org/10.1152/physiol.00018.2016

Mashek, D., Ingvartsen, K., Andersen, J., Vestergaard, M., \& Larsen, T. (2001). Effects of a four-day hyperinsulinemic-euglycemic clamp in early and mid-lactation dairy cows on plasma concentrations of metabolites, hormones, and binding proteins. Domestic Animal Endocrinology, 21, 169-85. https://doi.org/ 10.1016/S0739-7240(01)00112-6

McNamara, J. (2004). Research, improvement and application of mechanistic, biochemical, dynamic models of metabolism in lactating dairy cattle. Animal Feed Science and Technology, 112, 155-176. https://doi.org/ 10.1016/j.anifeedsci.2003.10.010

McNamara, J. (2015). Systems biology or regulation of regulatory mechanisms in support to lactation. Journal of Animal Science 93, 5575-5585. https://doi.org/10.2527/jas.2015-9010

McNamara, J., \& Hilllers, J. (1986). Regulation of bovine adipose tissue metabolism during lactation. 2. Lipolysis response to milk production and energy intake. Journal of Dairy Science, 69, 3042-3050. https://doi.org/ 10.3168/jds.S0022-0302(86)80767-6

Mendonca, L., Litherland, N., Lucy, M., Keisler, D., Ballou, M., Hansen, L., \& Chebel, R. (2013). Comparison of innate immune responses and somatotropic axis components of Holstein and Montbéliarde-sired crossbred dairy cows during the transition period. Journal of Dairy Science, 93, 3588-3598. https://doi.org/ $10.3168 /$ jds.2012-5804

Miller, R., Kuhn, M., Norman, H., \& Wright, J. (2008). Death losses for lactating cows in herds enrolled in dairy herd improvement test plans. Journal of Dairy Science, 91, 3710-3715. https://doi.org/10.3168/jds. 2007-0943

Moares, L., Kebreab, E., Strathe, A., Dijkstra, J., France, J., Casper, D., \& Fadel, J. (2015). Multivariate and univariate analysis of energy balance data from lactating dairy cows. Journal of Dairy Science, 98, 4012-4029. https://doi.org/10.3168/jds.2014-8995

Montgomery, S., Mamedova, L., Zachut, M., Kra, G., Häussler, S., Vaughn, M., \& Bradford, B. (2019). Effects of sodium salicylate on glucose kinetics and insulin signaling in postpartum dairy cows. Journal of Dairy Science, 102, 1617-1629. https://doi.org/10.3168/jds.2018-15312

Moyes, K., Larsen, T., \& Ingvartsen, K. (2013). Generation of an index for physiological imbalance and its use as a predictor of primary disease in dairy cows during early lactation. Journal of Dairy Science, 96, 2161-2170. https://doi.org/10.3168/jds.2012-5646

National Research Council. (2001). Nutrient Requirement of Dairy Cattle (7th ed., pp. 22-25). National Academy of Science, Washington DC.

Neves, R., Leno, B., Bach, K., \& McArt, J. (2018). Epidemiology of subclinical hypocalcemia in early-lactation Holstein dairy cows: The temporal associations of plasma calcium concentration in the first 4 days in milk with disease and milk production. Journal of Dairy Science, 101, 9321-9331. https://doi.org/10.3168/ jds.2018-14587

O'Connor, A., \& Sargeant, J. (2014). An introduction to systematic reviews in animal health, animal welfare, and food safety. Animal Health Research Reviews, 15, 3-13. https://doi.org/10.1017/S146625231400005X

Oftedal, O. (1993). The adaptation of milk secretion to the constrains of fasting in bears, seals, and Baleen whales. Journal of Dairy Science, 76, 3234-3246. https://doi.org/10.3168/jds.S0022-0302(93)77660-2

Oftedal, O. (2012). The evolution of milk secretion and its ancient origins. Animal, 6, 355-358. https://doi.org/ $10.1017 /$ S1751731111001935 
Okamura, C., Bader, J., Keisler, D., \& Lucy, M. (2009). Short communication: Growth hormone receptor expression in two dairy breeds during the periparturient period. Journal of Dairy Science, 92, 2706-2710. https://doi.org/10.3168/jds.2008-1775

Oldham, J. (1984). Protein-energy relationship in dairy cow. Journal of Dairy Science, 67, 1090-1114. https://doi.org/10.3168/jds.S0022-0302(84)81410-1

Oldham, J., Hart, I., \& Bines, J. (1978). Effect of abomasal infusion of casein, arginine, methionine or phenyl-alanine on growth hormone, insulin, prolactin, thyroxine and some metabolites in blood from lactating goats. Proceedings of the Nutrition Society, 37, 9A.

Ørskov, E., Grubb, D., \& Kay, R. (1977). Effect of postruminal glucose or protein supplementation on milk yield and composition in Friesian cows in early lactation and negative energy balance. British Journal of Nutrition, 38, 397-405. https://doi.org/10.1079/bjn19770104

Ørskov, E., Reid, G., \& McDonald, I. (1981). The effect of protein degradability and food intake on milk yield and composition in cows in early lactation. British Journal of Nutrition, 45, 547-555. https://doi.org/ 10.1079/bjn19810133

Ørskov, E., Reid, G., \& Tait, C. (1987). Effect of fish meal on the mobilization of body energy in dairy cows. Animal Production, 45, 345-348. https://doi.org/10.1017/S000335610000283X

Osorio, J., Ji, P., Drackley, J., Luchini, D., \& Loor, J. (2014). Smartamine M and MetaSmart supplementation during the peripartal period alter hepatic expression of gene networks in 1-carbon metabolism, inflammation, oxidative stress, and the growth hormone-insulin-like growth factor 1 axis pathways. Journal of Dairy Science, 97, 7451-7564. https://doi.org/10.3168/jds.2014-8680

Patton, J., Kenny, D., Mee O’Mara, F., Wathes, D., Cook, M., \& Murphy, J. (2006). Effect of milking frequency and diet on milk production, energy balance and reproduction in dairy cows. Journal of Dairy Science, 89, 1478-1487. https://doi.org/10.3168/jds.S0022-0302(06)72215-9

Radcliff, P., McCormick, B., Keisler, D., Crooker, B., \& Lucy, M. (2006). Partial feed restriction decreases growth hormone receptor 1A mRNA expression in postpartum dairy cows. Journal of Dairy Science, 89, 611-619. https://doi.org/10.3168/jds.S0022-0302(06)72124-5

Radcliff, R., McCormack, B., Crooker, B., \& Lucy, M. (2003). Growth hormone (GH) binding and expression of GH receptor 1A mRNA in hepatic tissue of periparturient dairy cows. Journal of Dairy Science, 86, 3933-3940. https://doi.org/10.3168/jds.S0022-0302(03)74002-8

Reid, I., \& Roberts, J. (1982). Fat liver in dairy cows. In Practice, 11, 164-169. https://doi.org/10.1136/inpract. 4.6.164

Renaville, R., Hammadi, M., \& Portetelle, D. (2002). Role of somatotropic axis in the mammalian metabolism. Domestic Animal Endocrinology, 23, 351-360. https://doi.org/10.1016/S0739-7240(02)00170-4

Rhoads, R., Kim, J., Leury, B., Baumgard, L., Segoale, N., Frank, S., \& Boisclair, Y. (2004). Insulin increases the abundance of the growth hormone receptor in liver and adipose tissue of periparturient cows. Journal of Nutrition, 134, 1920-1927. https://doi.org/10.1093/jn/134.5.1020

Roche, J. (2006). The effect of nutritional management of the dairy cow on reproductive efficiency. Animal Reproduction Science, 96, 282-296. https://doi.org/10.1016/j.anireprosci.2006.08.007

Roche, J., Friggens, N., Kay, J., Fisher, M., Stafford, K., \& Berry, D. (2009). Invited review: Body condition score and its association with dairy cow productivity, health, and welfare. Journal of Dairy Science, 92, 5769-5801. https://doi.org/10.3168/jds.2009-2431

Ronge, H., \& Blum, J. (1989). Insulin like growth factor I response to growth hormone in dry and lactating cows. Journal of Animal Physiology and Animal Nutrition, 62, 280-288. https://doi.org/10.1111/j.1439-0396. 1989.tb00845.x

Scharrer, E. (1999) Control of food intake by fat acid oxidation and ketogenesis. Nutrition, 15, $704-714$. https://doi.org/10.1016/S0899-9007(99)00125-2

Schiaffino, S., Dyar, K., Ciciliot, S., Blaauw, B., \& Sandri, M. (2013). Mechanisms regulating skeletal muscle growth and atrophy. The FEBS Journal, 280, 4294-314. https://doi.org/10.1111/febs.12253 
Schlegel, G., Ringseis, R., Keller, J., Schwarz, F., Windisch, W., \& Eder, K. (2013). Expression of fibroblast growth factor 21 in the liver of dairy cows in the transition period and during lactation. Journal of Animal Physiology and Animal Nutrition, 97, 820-829. https://doi.org/10.1111/j.1439-0396.2012.01323.x

Schoenberg, K., Giesy, S., Harvatine, K., Waldron, M., Cheng, C., Kharitonenkov, A., \& Boisclair, Y. (2011). Plasma FGF21 is elevated by the intense lipid mobilization of lactation. Endocrinology, 152, 4652-4661. https://doi.org/10.1210/en.2011-1425

Schröder, U., \& Staufenbiel, R. (2006). Invited review: Methods to determine body fat reserves in the dairy cow with special regard to ultrasonographic measurement of backfat thickness. Journal of Dairy Science, 89, 1-14. https://doi.org/10.3168/jds.S0022-0302(06)72064-1

Secor, S., \& Carey, H. (2016). Integrative physiology of fasting. Comprehensive Physiology, 6, $773-825$. https://doi.org/10.1002/cphy.c150013

Sheehy, M., Fahey, A., Aungier, S., Carter, F., Crowe, M., \& Mulligan, F. (2017). A comparison of serum metabolic and production profiles of dairy cows that maintained or lost body condition 15 days before calving. Journal of Dairy Science, 100, 536-537. https://doi.org/10.3168/jds.2016-11206

Sheldon, M., Cronin, J., Pospiech, M., \& Turner, M. (2018). Symposium Review: Mechanisms linking metabolic stress with innate immunity in the endometrium. Journal of Dairy Science, 101, 3655-3664. https://doi.org/ $10.3168 /$ jds.2017-13135

Shonka, B., Tao, S., Dahl, G., \& Spurlock, D. (2015). Genetic regulation of prepartum dry matter intake in Holstein cows. Journal of Dairy Science, 98, 8195-8200 https://doi.org/10.3168/jds.2015-9675

Siegel, H. (1995). Stress, strains and resistance. British Poultry Science, 36, 3-22. https://doi.org/10.1080/ 00071669508417748

Sordillo, L., \& Mavangira, V. (2014). The nexus between nutrient metabolism, oxidative stress and inflammation in transition cows. Animal Production Science, 54, 1204-1214. https://doi.org/10.1071/AN14503

Spurlock, D., Dekkers, J., Fernando, R., Koltes, D., \& Wolc, A. (2012). Genetic parameters for energy balance, feed efficiency, and related traits in Holstein cattle. Journal of Dairy Science, 93, 5393-5402. https://doi.org/10.3168/jds.2012-5407

Staiger, H., Keuper, M., Berti, L., Hrabe de Angelis, M., \& Häring, H. (2017). Fibroblast growth factor 21-Metabolic role in mice and men. Endocrine Reviews, 38, 468-488. https://doi.org/10.1210/er.2017-00016

Steinwidder, A., \& Gruber, L. (2002). Leistungsgrenzen der Milchkuh im Biolandbau und konventionell Haltung (pp. 13-35). Seminar "Leistungszucht und Leistungsgrenzen beim Rind", Genetischer Ausschuss der ZAR, Salzburg.

Sundrum, A. (2015). Metabolic disorders in the transition period indicate that the dairy cows' ability to adapt is overstressed. Animals, 5, 978-1020. https://doi.org/10.3390/ani5040395

Sutter, F., \& Beever, D. (2000). Energy and nitrogen metabolism in Holstein-Friesian cows during early lactation. Animal Science, 70, 503-514. https://doi.org/10.1017/S1357729800051857

Tamminga, S., Luteijn, P., \& Meijer, R. (1997). Changes in composition and energy content of live weight loss in dairy cows with time after parturition. Livestock Production Science, 52, 31-38. https://doi.org/10.1016/ S0301-6226(97)00115-2

Van den Top, A., van Tol, A., Jansen, H., Geelen, M., \& Beynen, A. (2005). Fat liver in dairy cows postpartum is associated with decreased concentration of plasma triacylglycerols and decreased activity of lipoprotein lipase in adipocytes. Journal of Dairy Research, 72, 129-137. https://doi.org/10.1017/S0022029905000774

Van Knegsel, A., de Vries Reilingh, G., Meulenberg, S., van den Brand, H., Dijkstra, J., Kemp, B., \& Parmentier, H. (2007b). Natural antibodies related to energy balance in early lactation dairy cows. Journal of Dairy Science, 90, 5490-5498. https://doi.org/10.3168/jds.2007-0289

Van Knegsel, A., van den Brand, H., Dijkstra, J., van Straalen, W., Jorritsma, R., Tamminga, S., \& Kemp, B. (2007a). Effect of glucogenic vs. lipogenic diets on energy balance, blood metabolites, and reproduction in primiparous and multiparous dairy cows in early lactation. Journal of Dairy Science, 90, 3397-3409. https://doi.org/10.3168/jds.2006-837 
Van Saun, R., \& Sniffen, C. (2014). Transition cow nutrition and feeding management for disease prevention. Veterinary Clinics of North America: Food Animal Practice, 30, 689-719. https://doi.org/10.1016/j.cvfa. 2014.07.009

Van Straten, M., Shpigel, N., \& Friger, M. (2008). Analysis of body daily weight of high-producing dairy cows in the first one hundred twenty days of lactation and associations with ovarian inactivity. Journal of Dairy Science, 91, 3353-3362. https://doi.org/10.3168/jds.2008-1020

Veerkamp, R., \& Koenen, E. (1999). Multi-trait covariance functions to estimate genetic correlations between milk yield, dry-matter intkae and live during lactation. In J. Oldham, G. Simm, A. Groen, B. Nielsen, J. Pryce, \& T. Lawrence (Eds.), Metabolic stress in dairy cows. British Society of Animal Science Occasional Publication (No. 24, pp. 247-151). Pencuit, Midlothian: British Society of Animal Science. https://doi.org/ $10.1017 /$ S1463981500043168

Veerkamp, R., \& Thompson, R. (1999). Metabolic loads to be expected from different genotypes under different systems. In J. Oldham, G. Simm, A. Groen, B. Nielsen, J. Pryce, \& T. Lawrence (Eds.), Metabolic stress in dairy cows. British Society of Animal Science Occasional Publication (No. 24, pp. 27-35). Pencuit, Midlothian: British Society of Animal Science.

Veerkamp, R., Beerda, B., \& Van der Lende, T. (2003). Effects of genetic selection for milk yield on energy balance, levels of hormones, and metabolites in lactating cattle, and possible links to reduced fertility. Livestock Production Science, 83, 257-275. https://doi.org/10.1016/S0301-6226(03)00108-8

Velloso, P. (2008). Regulation of muscle mass by growth hormone and IGF-I. British Journal of Pharmacology, 154, 557-568. https://doi.org/10.1038/bjp.2008.171

Vernon, R. (1989). Endocrine control of metabolic adaptation during lactation. Proceedings of the Nutrition Society, 48, 23-32. https://doi.org/10.1079/pns19890006

Vernon, R. (1998). Homeorhesis (pp. 64-73). Hannah Research Institute.

Vernon, R., \& Pond, C. (1997). Adaptation of maternal adipose tissue to lactation. Journal Mammary Gland and Biology of Neoplasia, 2, 231-241.https://doi.org/10.1023/a:1026380220364

Wall, E., \& McFadden, T. (2012). Triennial Lactation Symposium: A local affair: How the mammary gland adapts to changes in milking frequency. Journal of Animal Science, 90, 1695-1707. https://doi.org/10.2527/ jas.2011-4790

Waltner, S., McNamara, J., \& Hillers, J. (1993). Relationship of body condition scores of production variables in high producing Holstein dairy cattle. Journal of Dairy Science, 76, 3410-3419. https://doi.org/10.3168/ jds.S0022-0302(93)77679-1

Warko, G., \& Bostedt, H. (1993). Zur Entwicklung der IgG-Konzentration im Blutserum neugeborener Fohlen. Tierärztliche Praxis, 21, 528-535.

Wathes, D., Cheng, Z., Bourne, N., Taylor, V., Coffey, M., \& Brotherstone, S. (2007). Differences between primiparous and multiparous dairy cows in the inter-relationships between metabolic traits, milk yield and body condition score in the periparturient period. Domestic Animal Endocrinology, 33, 203-25. https://doi.org/10.1016/j.domaniend.2006.05.004

Whitelaw, F., Milne, J., Ørskov, E., \& Smith, J. (1986). The nitrogen an energy metabolism of lactating cows given abomasal infusion of casein. British Journal of Nutrition, 55, 437-556. https://doi.org/10.1079/ BJN19860061

Winkelman, L., Lucy, M., Elsasser, T., Pate, J., \& Reynolds, C. (2008). Short communication: Suppressor of cytokine signaling-2 mRNA increases after parturition in the liver of dairy cows. Journal of Dairy Science, 91, 1080-1086. https://doi.org/10.3168/jds.2007-0433

Xu, J., Lloyd, D., Hale, C., Stanislaus, S., Chen, M., Sivits, G., \& Véniant, M. (2009). Fibroblast growth factor 21 reverse hepatic steatosis, increases energy expenditure, and improves insulin sensitivity in diet-induced obese mice. Diabetes, 58, 250-259. https://doi.org/10.2337/db08-0392

Zachut, M., Honig, H., Striem, S., Zick, Y., Boura-Halfon, S., \& Moallem, U. (2013). Periparturient dairy cows don not exhibit hepatic insulin resistance, yet adipose-specific insulin resistance occurs in cows prone to high weight loos. Journal of Dairy Science, 96, 5656-5669. https://doi.org/10.3168/jds.2012-6142 
Zinicola, M., \& Bicalho, R. (2019). Association of peripartum plasma insulin concentration with milk production, colostrum insulin levels, and plasma metabolites of Holstein cows. Journal of Dairy Science, 102, 1473-1482. https://doi.org/10.3168/jds.2017-14029

\section{Copyrights}

Copyright for this article is retained by the author(s), with first publication rights granted to the journal.

This is an open-access article distributed under the terms and conditions of the Creative Commons Attribution license (http://creativecommons.org/licenses/by/4.0/). 